\title{
Tropical atmospheric circulation response to the $G 1$ sunshade geoengineering radiative forcing experiment
}

\author{
Anboyu Guo ${ }^{1}$, John C. Moore ${ }^{1,2,3}$, and Duoying $\mathbf{J i}^{1}$ \\ ${ }^{1}$ College of Global Change and Earth System Science, Beijing Normal University, 19 Xinjiekou Wai St., \\ Beijing 100875, China \\ ${ }^{2}$ Arctic Centre, University of Lapland, P.O. Box 122, 96101 Rovaniemi, Finland \\ ${ }^{3}$ CAS Center for Excellence in Tibetan Plateau Earth Sciences, Beijing 100101, China
}

Correspondence: John C. Moore (john.moore.bnu@gmail.com)

Received: 6 February 2018 - Discussion started: 15 February 2018

Revised: 16 May 2018 - Accepted: 26 May 2018 - Published: 20 June 2018

\begin{abstract}
We investigate the multi-Earth system model response of the Walker circulation and Hadley circulations under the idealized solar radiation management scenario (G1) and under abrupt $4 \mathrm{xCO} 2$. The Walker circulation multi-model ensemble mean shows changes in some regions but no significant change in intensity under $\mathrm{G} 1$, while it shows a $4^{\circ}$ eastward movement and $1.9 \times 10^{9} \mathrm{~kg} \mathrm{~s}^{-1}$ intensity decrease in abrupt $4 \mathrm{xCO} 2$. Variation in the Walker circulation intensity has the same high correlation with sea surface temperature gradient between the eastern and western Pacific under both G1 and abrupt $4 x \mathrm{CO} 2$. The Hadley circulation shows significant differences in behavior between $\mathrm{G} 1$ and abrupt4xCO2, with intensity reductions in the seasonal maximum northern and southern cells under G1 correlated with equatorward motion of the Intertropical Convergence Zone (ITCZ). Southern and northern cells have a significantly different response, especially under abrupt $4 \mathrm{xCO} 2$ when impacts on the southern Ferrel cell are particularly clear. The southern cell is about $3 \%$ stronger under abrupt $4 \mathrm{xCO} 2$ in July, August and September than under piControl, while the northern is reduced by $2 \%$ in January, February and March. Both circulations are reduced under G1. There are significant relationships between northern cell intensity and land temperatures, but not for the southern cell. Changes in the meridional temperature gradients account for changes in Hadley intensity better than changes in static stability in G1 and especially in abrupt $4 x \mathrm{CO} 2$. The difference in the response of the zonal Walker circulation and the meridional Hadley circulations under the idealized forcings may be driven by the zonal symmetric relative cooling of the tropics under G1.
\end{abstract}

\section{Introduction}

Large-scale tropical atmospheric circulation may be partitioned into two independent orthogonal overturning convection cells, namely the Hadley circulation $(\mathrm{HC})$ and the Walker circulation (WC; Schwendike et al., 2014). The HC is the zonally symmetric meridional circulation with an ascending branch in the Intertropical Convergence Zone (ITCZ) and a descending branch in the subtropical zone and which plays a critical role in producing tropical and subtropical climatic zones, especially deserts (Oort and Yienger, 1996). The WC is the asymmetric zonal circulation, which extends across the entire tropical Pacific, characterized by an ascending center over the Maritime Continent and western Pacific, eastward moving air flow in the upper troposphere, a strong descending center over the eastern Pacific and surface trade winds blowing counter to the upper winds along the equatorial $\mathrm{Pa}-$ cific completing the circulation (Bjerknes, 1969).

Observational evidence shows a poleward expansion of the $\mathrm{HC}$ in the past few decades (Hu et al., 2011) and an intensification of the HC in the boreal winter (Song and Zhang, 2007). Climate model simulations with increased greenhouse gas forcing also indicate a poleward expansion of the Hadley circulation (Hu et al., 2013; Ma and Xie, 2013; Kang and Lu, 2012; Davis et al., 2016). Vallis et al. (2015) analyzed the response of 40 CMIP5 climate models, finding that there was only modest model agreement on changes. Robust results were a slight expansion and weakening of the winter cell HC in the Northern Hemisphere (NH). It is unclear how closely the model simulations match reality. Choi et al. (2014) and Quan et al. (2014) both suggest that reanalysis trends for the 
Hadley cell edges may be overstated, especially compared to independent observations, and model trends are in reasonable agreement with the reanalysis trends (Davis and Birner, 2017; Garfinkel et al., 2015), but choice of metric also matters (Solomon et al., 2016) when discussing trends.

Many authors have considered the impact of greenhouse gas forcing on the Hadley circulation, particularly with respect to changes in the width of the tropical belt (e.g., Frierson et al., 2007; Grise and Polvani, 2016; Johanson and Fu, 2009; Lu et al., 2007; Seidel et al., 2008), but far fewer have discussed changes in Hadley intensity (Seo et al., 2014; He and Soden, 2015). The importance of tropical belt widening is of course due to its impact on the hydrological system, especially the locations of the deserts (Lau and Kim, 2015; Seager et al., 2010), which are critically important for the habitability of several well-populated areas.

Observational evidence shows a strengthening and westward movement of the WC from 1979 to 2012 (Bayr et al., 2014; Ma and Zhou, 2016). However, the time required to robustly detect and attribute changes in the tropical Pacific WC could be 60 years or more (Tokinaga et al., 2012). Model results suggest a significant eastward movement with weakening intensity under greenhouse gas forcing (Bayr et al., 2014), and He and Soden (2015) propose that sea surface temperature warming plays a crucial role in both the eastward shift and the weakening of the WC. They also note that this weakening may be reversed by rapid land warming.

Geoengineering as a method of mitigating the deleterious effects of anthropogenic climate change has been suggested as a complement to mitigation and adaptation efforts. For example, Shepherd (2009) summarized the methodologies and governance implications as early as a decade ago. Solar radiation management (SRM) geoengineering can lessen the effect of global warming due to the increasing concentrations of greenhouse gases by reducing incoming solar radiation. This compensation of longwave radiative forcing with shortwave reductions necessarily leads to nonuniform effects around the globe, as summarized in results for many climate models in the Geoengineering Model Intercomparison Project (GeoMIP) by Kravitz et al. (2013). This is due to the seasonal and diurnal patterns of shortwave forcing being far different from the almost constant longwave radiative absorption. In addition, SRM tends to produce net drying due to the decreasing vertical temperature gradient as greenhouse gasses (GHGs) increase absorption in the troposphere, while shortwave radiative forcing affects surface temperatures (Bala et al., 2011). These differences in shortwave and longwave forcing impacts atmospheric circulation and hence precipitation patterns, summarized for the GeoMIP models by Tilmes et al. (2013). The general pattern of temperature change under abrupt $4 \mathrm{xCO} 2$ includes accentuated Arctic warming and the least warming in the tropics. G1 largely reverses these changes, but leaves some residual warming in the polar regions and under-cools the tropics relative to piControl. SRM also reduces temperatures over land more than over oceans relative to abrupt $4 \mathrm{xCO} 2$ and hence reduces the temperature difference between land and oceans by about $1{ }^{\circ} \mathrm{C}$. Extreme precipitation is affected by SRM such that heavy precipitation events become rarer, while small and moderate events become more frequent (Tilmes et al., 2013). This is generally opposite to the impact of GHG forcing alone, which tends to produce a "wet gets wetter and dry gets drier" pattern to global precipitation anomalies (Tilmes et al., 2013; Held and Soden, 2006). Finally, tropical extreme cyclones have been shown to be affected by SRM in ways that do not simply reflect changes in tropical sea surface temperatures due to large-scale planetary circulations and teleconnection patterns (Moore et al., 2015).

To date, few studies of the impact of SRM on tropical atmospheric circulation have been published. Ferraro et al. (2014), using an intermediate complexity climate model, found tropical overturning circulation weakens in response to SRM with stratospheric sulfate aerosol injection. But SRM simulated as a simple reduction in total solar irradiance does not capture this effect. Davis et al. (2016) analyzed nine GeoMIP models and report that the HC expands in response to a quadrupling of atmospheric carbon dioxide concentrations more or less proportionality to the climate sensitivity of the climate model and shrinks in response to a reduction in solar constant. Smyth et al. (2017) report that decreases in Hadley cell intensity drive the reduction in tropical precipitation under SRM, and that seasonal changes mean that the ITCZ has smaller-amplitude northward shifts compared with no SRM.

The El Niño-Southern Oscillation (ENSO) is the largest mode of multi-annual variability exhibited by the climate system in terms of its temperature variability and also for its socioeconomic impacts. This tropical circulation pattern is intimately related to changes in the WC by their dependences on the Pacific Ocean zonal sea surface temperature gradient and indirectly to the $\mathrm{HC}$ by its impacts on global energy balance. Few studies of climate model ENSO response to SRM have been made, with Gabriel and Robock (2015) finding that stratospheric aerosol injection by the GeoMIP G4 experiment produces no significant impacts on El NiñoSouthern Oscillation. The SRM and GHG forcing in the G4 experiment are both relatively low compared with the G1 experiment, since under G4 the GHG scenario is the modest RCP4.5, which means that natural climate variability in the 50 -year-long period of SRM may obscure features. However, this topic is worthy of more investigation since one concern is that SRM will place the climate system into a new regime of variability (Robock, 2008; Shepherd, 2009). If this were the case then we expect that the dominant climate modes of variability would also differ from both preindustrial conditions and those under GHG forcing alone. Although this can be studied via volcanic analogues, they are imperfect due to their transient nature compared with the long-term deployment of SRM (Robock et al., 2008). Tropical volcanic eruptions do indeed change the global circulation (Robock, 2000), and so climate mode change is a potential risk of 
SRM. Hence examining the tropical circulations and their response under ENSO modulation can provide evidence on the likelihood of SRM inducing a regime change on the global climate system.

In this paper we utilize simulation results from eight Earth system models (ESMs) that participated in the GeoMIP G1 experiment (Kravitz et al., 2011) and compare these results with the corresponding Climate Model Intercomparison Project Phases 5 (CMIP5) experiment for the abrupt quadrupling of $\mathrm{CO}_{2}$ (abrupt4xCO2) and preindustrial conditions (piControl). The G1 scenario is the largest SRM signal addressed to date by experiments given that it is designed to balance radiative forcing from quadrupled $\mathrm{CO}_{2}$; hence the signal to noise ratio is high, and furthermore it has been completed a by a large number of ESMs and so we can examine across model differences in simulations. We address the following key questions: does the G1 scenario counteract position and intensity variations in the Walker and Hadley circulations caused by the GHG longwave forcing under abrupt $4 \mathrm{xCO} 2$ ? How does the tropical atmospheric circulation, including the Walker and Hadley circulations, respond to warm and cold phases of the El Niño-Southern Oscillation in $\mathrm{G} 1$ and abrupt4xCO2?

\section{Data and methods}

We use eight ESMs (Table 1), a subset of the group described in Kravitz et al. (2013), that have completed G1. We are limited to these models due to the unavailability of some fields in the output from other models. The simulations in each model are initiated from a preindustrial condition that has reached steady state, denoted as piControl, which is the standard CMIP5 name for this experiment (Taylor et al., 2012). Our reference simulation, denoted abrupt $4 \times \mathrm{xCO} 2$, is also a standard CMIP5 experiment in which $\mathrm{CO}_{2}$ concentrations are instantaneously quadrupled from the control run. This experiment implies an atmospheric $\mathrm{CO}_{2}$ concentration of nearly $1140 \mathrm{ppm}$, close to concentrations under "business as usual" scenarios such as RCP8.5 by the year 2100. Experiment G1 in GeoMIP involves an instantaneous reduction of insolation simultaneous with this $\mathrm{CO}_{2}$ increase such that topof-atmosphere (TOA) radiation differences between G1 and piControl are no more than $0.1 \mathrm{~W} \mathrm{~m}^{-2}$ for the first 10 years of the 50-year experiment (Kravitz et al., 2011). The amount of solar radiation reduction is model dependent but does not vary during the course of the simulation.

We used the following variables from eight climate models and reanalysis data (Table 1): sea level pressure (SLP), sea surface temperature (SST), zonal wind $(U)$, meridional wind $(V)$, sea level pressure and sea surface temperature interpolated onto a regular $1^{\circ} \times 1^{\circ}$ grid. The zonal and meridional winds are regridded onto a common horizontal fixed grid of $2.5^{\circ} \times 2.5^{\circ}$ as in many preceding studies (Bayr et al., 2014; Ma and Zhou, 2016; Stachnik and Schumacher, 2011). We used monthly mean model output data. Reanalysis data span the years 1979-2016.

Composite analysis is applied for the study on the influence of ENSO. We follow Bayr et al. (2014) and use detrended and normalized Niño 3.4 index (monthly averaged sea surface temperature anomaly in the region bounded by $5^{\circ} \mathrm{N}-5^{\circ} \mathrm{S}$, from $170-120^{\circ} \mathrm{W}$ ) as a criteria to select ENSO events. An index $>1$ represents an El Niño event and $<-1$ a La Niña one (Bayr et al., 2014). We concatenate variables in all El Niño and La Niña events for each individual model to get El Niño and La Niña data sets and then calculate ensemble results.

\subsection{Mass stream function}

The HC and WC represent the meridional and zonal components of the complete three-dimensional tropical atmospheric circulation. We follow many previous authors (e.g., Davis et al., 2016; Bayr et al., 2014; Nguyen et al., 2013; Ma and Zhou, 2016; Yu et al., 2012) in using mass stream function to conveniently separate and picture these two convective flows.

The zonal mass stream function $\left(\psi_{\mathrm{z}}\right)$ and meridional mass stream function $\left(\psi_{\mathrm{m}}\right)$ are defined as follows:

$\psi_{\mathrm{z}}=\frac{2 \pi a}{g} \int_{0}^{p_{\mathrm{s}}} u_{D} \mathrm{~d} p$,

$\psi_{\mathrm{m}}=\frac{2 \pi a \cos (\phi)}{g} \int_{0}^{p_{\mathrm{s}}} v \mathrm{~d} p$,

where $u_{D}$ and $v$ respectively represent the divergent component of the zonal wind and the zonal mean meridional wind, $a$ is the radius of Earth, $g$ is the acceleration of gravity $\left(9.8 \mathrm{~m} \mathrm{~s}^{-2}\right), p$ is the pressure, $p_{\mathrm{s}}$ is the surface pressure and the $\phi$ in Eq. (2) is latitude. The meridionally averaged $u_{D}$ values between $5^{\circ} \mathrm{S}$ and $5^{\circ} \mathrm{N}$ are integrated from the top of the atmosphere to the surface in calculating the zonal mass stream function $\left(\psi_{\mathrm{z}}\right)$.

Some previous studies have removed the fast response transient and only use years $11-50$ of G1 and abrupt $4 \times \mathrm{xCO} 2$ to avoid climate transient effects (e.g., Smyth et al., 2017; Kravitz et al., 2013), while Davis et al. (2016) discarded the first 5 years, noting that the choice is conservative. We examine whether the zonal and meridional mass stream functions have transient effects at the start of the simulation (Fig. S1 in the Supplement). We show the time series of the WC as defined by the vertically averaged value of the stream function $\psi_{\mathrm{z}}$ (STRF; see Sect. 2.2) and show that there is variability at many timescales up to decadal but without significant transient effects. This is confirmed by statistical analysis of each model; for example, there are four models (CCSM4, HadGEM2-ES, IPSL-CM5A-LR and MIROCESM) that have significantly $(p<0.05)$ higher STRF in the first 10 years of the abrupt $4 \mathrm{xCO} 2$ simulation than in the following decades. This is not due to a transient affecting the 
Table 1. The GeoMIP and CMIP5 models and the reanalysis data used in the paper.

\begin{tabular}{llll}
\hline No. & Model $^{*}$ & Reference & Lat $\times$ Lon \\
\hline 1 & BNU-ESM & Ji et al. (2014) & $2.8^{\circ} \times 2.8^{\circ}$ \\
2 & CanESM2 & Arora et al. (2011) & $2.8^{\circ} \times 2.8^{\circ}$ \\
3 & CCSM4 & Gent et al. (2011) & $0.9^{\circ} \times 1.25^{\circ}$ \\
4 & GISS-E2-R & Schmidt et al. (2014) & $2^{\circ} \times 2.5^{\circ}$ \\
5 & HadGEM2-ES & Collins et al. (2011) & $1.25^{\circ} \times 1.875^{\circ}$ \\
6 & IPSL-CM5A-LR & Dufresne et al. (2013) & $2.5^{\circ} \times 3.75^{\circ}$ \\
7 & MIROC-ESM & Watanabe et al. (2011) & $2.8^{\circ} \times 2.8^{\circ}$ \\
8 & NorESM1-M & Bentsen et al. (2013), Iversen et al. (2013) & $1.9^{\circ} \times 2.5^{\circ}$ \\
9 & NCEP-DOE (NCEP2) & Kanamitsu et al. (2002) & $2.5^{\circ} \times 2.5^{\circ}$ \\
10 & ERA-Interim & Simmons et al. (2007) & $0.75^{\circ} \times 0.75^{\circ}$ \\
\hline * Full Names: BNU-ESM, Beijing Normal University Earth System Model; CanESM2, the Second Generation Canadian \\
Earth System Model; CCSM4, the Community Climate System Model version 4; GISS-E2-R, Goddard Institute for Space \\
Studies ModelE version 2; IPSL-CM5A-LR, Institut Pierre Simon Laplace ESM; MIROC-ESM, Model for Interdisciplinary \\
Research on Climate-Earth System Model; NorESM1-M, Norwegian ESM.
\end{tabular}

first few years, but rather to higher values around 3 years into the simulation; this is not unusual for each model's multi-annual and decadal variability. On the other hand, the measures of circulation that rely on sea surface temperature (Fig. S2) show some difference in the first decade compared with later periods under abrupt $4 \mathrm{xCO} 2$. The Hadley cell vertically averaged stream function shows similar results and strong seasonal variability (not shown). Therefore to utilize as much data as possible and increase the robustness of our statistical analysis, we use all 50 years of G1 and abrupt $4 \mathrm{xCO} 2$ simulations. We use 100 years of piControl simulations as baseline climate for the same reason.

\subsection{Walker circulation index}

Four related indices have been used to characterize the WC intensity and its position. Tropical Pacific east-west gradients, defined by conditions in the Darwin region $\left(5^{\circ} \mathrm{S}-5^{\circ} \mathrm{N}\right.$, $\left.80-160^{\circ} \mathrm{E}\right)$ and the Tahiti region $\left(5^{\circ} \mathrm{S}-5^{\circ} \mathrm{N}, 160-80^{\circ} \mathrm{W}\right)$, of sea level pressure $(\triangle \mathrm{SLP})$ and temperature $(\triangle \mathrm{SST}$; Bayr et al., 2014; DiNezio et al., 2013; Ma and Zhou, 2016; Vecchi and Soden, 2007; Vecchi et al., 2006) are highly correlated for all three experiments discussed here with $R^{2}$ around 0.9 . Ma and Zhou (2016) used the vertically averaged value of the stream function $\psi_{\mathrm{Z}}$ (STRF) over the western and central Pacific $\left(150^{\circ} \mathrm{E}-150^{\circ} \mathrm{W}\right)$, and this is also very highly correlated with $\triangle$ SST and $\triangle$ SLP. As we are interested in the structure of the circulation, we use either the complete, longitudinally averaged stream function or the STRF in the rest of the paper.

To determine the WC movement in different experiments, we use the western edge of WC to represent its position. The western edge is defined by the zero value of the vertically averaged $\psi_{\mathrm{Z}}$ between 400 and $600 \mathrm{hPa}$ in the western Pacific $120-180^{\circ} \mathrm{E}$ (Ma and Zhou, 2016).

\subsection{Hadley circulation index}

Many authors have separated the northern and southern HC cells simply by dividing by hemisphere (e.g., Davis et al., 2016), but during the active periods of each cell, the circulation extends across the Equator into the opposite hemisphere. The boundary at the edge of the tropics is also known to move latitudinally but the circulation cell rapidly becomes weaker beyond the zero crossing of the rotation sense. To capture the variability of the $\mathrm{HC}$ cells we select the season of maximum intensity for each cell and measure the strength across its full latitudinal extent. Thus we define the HC intensity for the southern cell as the average meridional stream function between 900 and $100 \mathrm{hPa}$ over the area between $40^{\circ} \mathrm{S}$ and $15^{\circ} \mathrm{N}$ in July, August and September (JAS) and the northern cell as the absolute value of mean meridional stream function between $15^{\circ} \mathrm{S}$ and $40^{\circ} \mathrm{N}$ in January, February and March (JFM). We experimented with using narrower definitions of the Hadley cell $\left(38-15\right.$ or $\left.35-15^{\circ}\right)$ in the three experiments, finding almost the same systematic offsets in intensities across the models and experiments. This is also true for each hemisphere separately. Departures in model ensemble mean intensity across the three experiments for both hemispheres from an outer latitude of $40^{\circ}$ range from 6.6-7 and $13.8-14 \%$ with outer latitudes of 38 and $35^{\circ}$, respectively. So using the wide latitude bands we chose captures all the variability in the Hadley cells in all the models and experiments without introducing biases due to experiments or hemispheres. We use the $900-100 \mathrm{hPa}$ levels (whereas typically $200 \mathrm{hPa}$ has been the ceiling; e.g., Nguyen et al., 2013) to accommodate the raised tropopause under GHG forcing, while avoiding boundary effects. 


\section{Walker circulation response}

\subsection{Intensity}

The annual mean state of zonal mass stream function $\left(\psi_{\mathrm{z}}\right)$ calculated from eight ensemble member mean piControl, ERA-Interim reanalysis and the NCEP2 reanalysis results are shown in Fig. 1. Zonal mass stream function $\left(\psi_{\mathrm{z}}\right)$ can intuitively depict the WC, which exhibits its strongest convection (positive values) in the equatorial zone across the Pacific. The $\mathrm{WC}$ center is around $500 \mathrm{hPa}$ and $160^{\circ} \mathrm{W}$. Figure $1 \mathrm{~d}$ shows that the ERA-Interim circulation has an eastward displacement and the intensity measured by STRF is overestimated by $26 \%$ relative to ensemble piControl. There is a similar structure to the stream function differences between NCEP2 reanalysis and piControl, and the STRF is only overestimated by $3 \%$ relative to ensemble piControl.

The relative changes from piControl under G1 and abrupt $4 \mathrm{xCO} 2$ experiments are shown in Fig. 2. The features of WC are very similar in both the G1 and piControl experiments shown in Fig. 2a. In abrupt $4 \mathrm{xCO} 2$ differences are larger and include a rise in the vertical extent of the circulation and an eastward shift in Fig. 2b. This is quantifiably confirmed by the STRF index increase of just $0.3 \%$ in G1 but a significant decrease of $7 \%$ in abrupt $4 \times \mathrm{xOO} 2$ relative to piControl (Table 2). However, only five out of eight models agree on the sign of the changes in abrupt $4 \mathrm{xCO} 2$ and there is much diversity between individual models (Fig. S3).

\subsection{Position}

The vertically averaged zonal mass stream functions $\left(\psi_{\mathrm{z}}\right)$ for the ensemble means of the three experiments as a function of longitude are shown in Fig. 3. To quantitatively measure the position change in the $\mathrm{WC}$ we use the western edge index. The ERA-Interim and NCEP2 reanalysis data respectively show 10.5 and $18^{\circ}$ more easterly positions than the piControl state. The WC shifts $0.5^{\circ}$ westward in G1 and $4^{\circ}$ eastward in abrupt $4 \mathrm{xCO} 2$ relative to piControl for the multimodel ensemble mean. There is a significant change in the ensemble mean position and strength under abrupt $4 \mathrm{xCO} 2$, but not G1 in Table 2. However, only five out of eight models agree on the sign of the changes, so the inter-model differences are rather large in this case. In the G1 experiment, the WC strengthens over the western Pacific around 130 to $150^{\circ} \mathrm{E}$ and weakens over the eastern Pacific around 115 to $80^{\circ} \mathrm{W}$, indicating a westward movement relative to piControl (Table 2). Thus the pattern is the opposite of that seen under abrupt $4 \mathrm{xCO} 2$ in Fig. $3 b$.

Under G1 there is a westward shift in the ascending branch of the circulation from about 30 to about $20^{\circ} \mathrm{E}$ as indicated by comparing the red shaded region around $30^{\circ} \mathrm{E}$ in Fig. 2a with the piControl result in Fig. 1c. Figure S3 shows that the anomaly is present in CanESM2, CCSM4 and NorESM1-M, while three models show almost no change (and indeed are

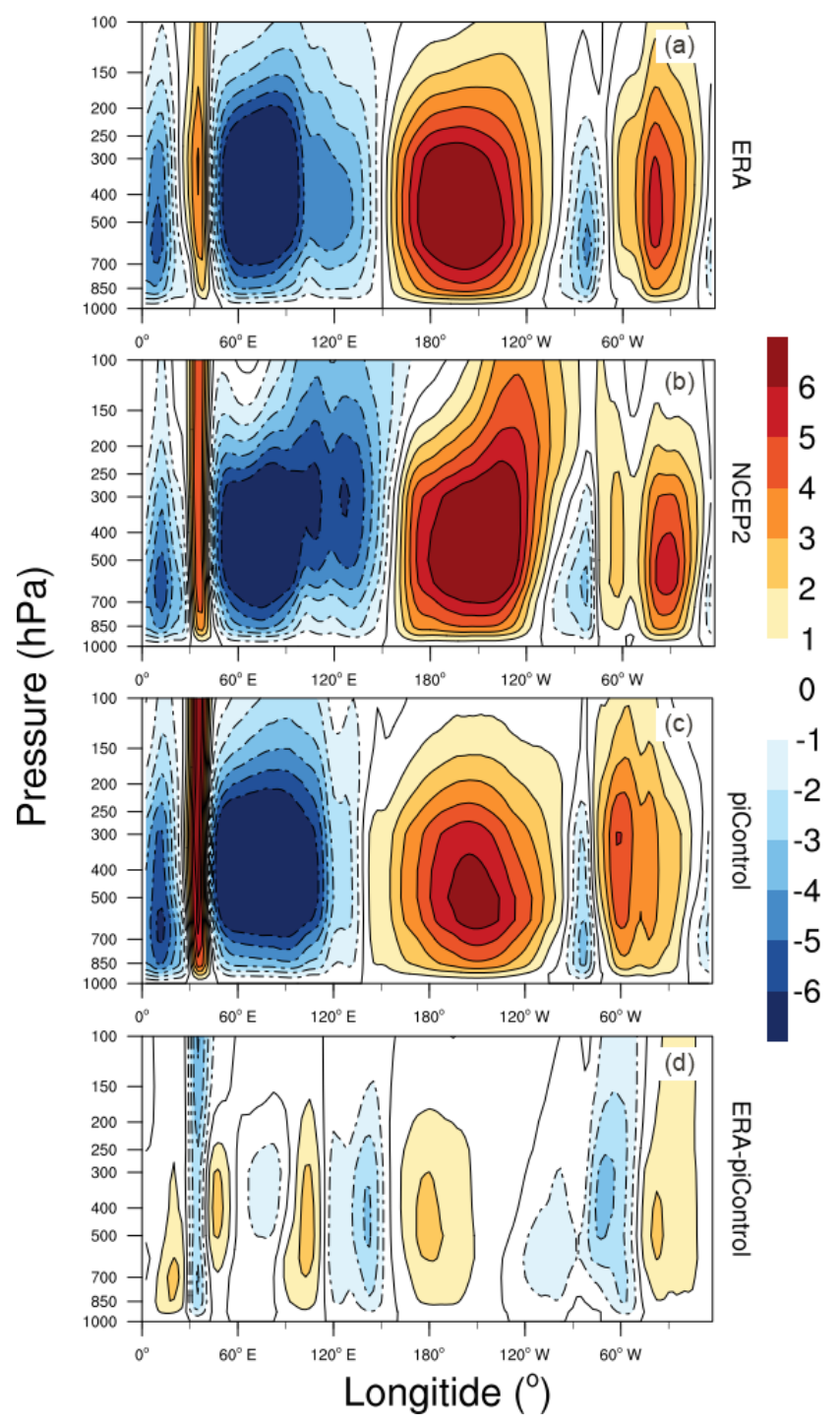

Figure 1. Walker circulation in the ERA-Interim reanalysis (a), NCEP2 reanalysis (b), model ensemble mean under piControl (c) and difference between ERA-Interim and piControl (d). Color bar indicates the value of averaged zonal mass stream function $\left(10^{10} \mathrm{~kg} \mathrm{~s}^{-1}\right)$. Warm colors (positive values) indicate a clockwise rotation and cold colors (negative values) indicate an anticlockwise rotation.

missing the African features in their piControl simulation). BNU-ESM shows the opposite anomaly, while GISS-E2-R shows a complex pattern. There is only a small change in the STRF zero crossing location in the region (Fig. 3b) because the anomalies are not vertical. This position is at the transition from tropical West African rain forest to wood and grassland in East Africa under present climates. The movement westward would impact the rain forests of the Congo basin. There is no similar positional change under abrupt $4 \mathrm{xCO} 2$ in the region, though there are many more changes in the circulation as a whole. 
Table 2. The change in Walker circulation position $\left(^{\circ}\right)$ and intensity $\left(10^{10} \mathrm{~kg} \mathrm{~s}^{-1}\right)$ in eight models and their ensemble mean. The number in the brackets represents the percentage of change relative to piControl. The negative position (STRF) represents westward movement (weakening) and a positive value represents eastward movement (strengthening). Statistically significant differences at $5 \%$ are in shown in bold.

\begin{tabular}{|c|c|c|c|c|}
\hline \multirow[t]{2}{*}{ Earth system model } & \multicolumn{2}{|c|}{ G1 } & \multicolumn{2}{|c|}{ abrupt $4 \mathrm{xCO} 2$} \\
\hline & Position & STRF & Position & STRF \\
\hline BNU-ESM & $0.32(0.2)$ & $-0.04(-2.3)$ & $8.6(5.8)$ & $-0.34(-18)$ \\
\hline CanESM2 & $3.8(2.7)$ & $-0.32(-11)$ & $16.4(11.5)$ & $-0.56(-19.3)$ \\
\hline CCSM4 & $-1(-0.7)$ & $0.5(20.6)$ & $-0.3(-0.2)$ & $0.58(24.6)$ \\
\hline GISS-E2-R & $10.6(6.5)$ & $-0.83(-73.5)$ & $21.2(13)$ & $-1.6(-143)$ \\
\hline HadGEM2-ES & $-1(-0.7)$ & $0.34(10.8)$ & $4.9(3.3)$ & $-0.14(-4.4)$ \\
\hline IPSL-CM5A-LR & $1.4(1)$ & $-1.8(-7.8)$ & $0.15(0.1)$ & $0.43(18.3)$ \\
\hline MIROC-ESM & $0.5(0.4)$ & $0.03(0.7)$ & $-5.2(-4.2)$ & $-0.72(-19.1)$ \\
\hline NorESM1-M & $-3.7(-2.3)$ & $0.56(20.2)$ & $-6.6(-4.2)$ & $0.93(33.6)$ \\
\hline Ensemble & $-0.5(-0.3)$ & $0.007(0.3)$ & $4(2.8)$ & $-0.19(-7.1)$ \\
\hline
\end{tabular}

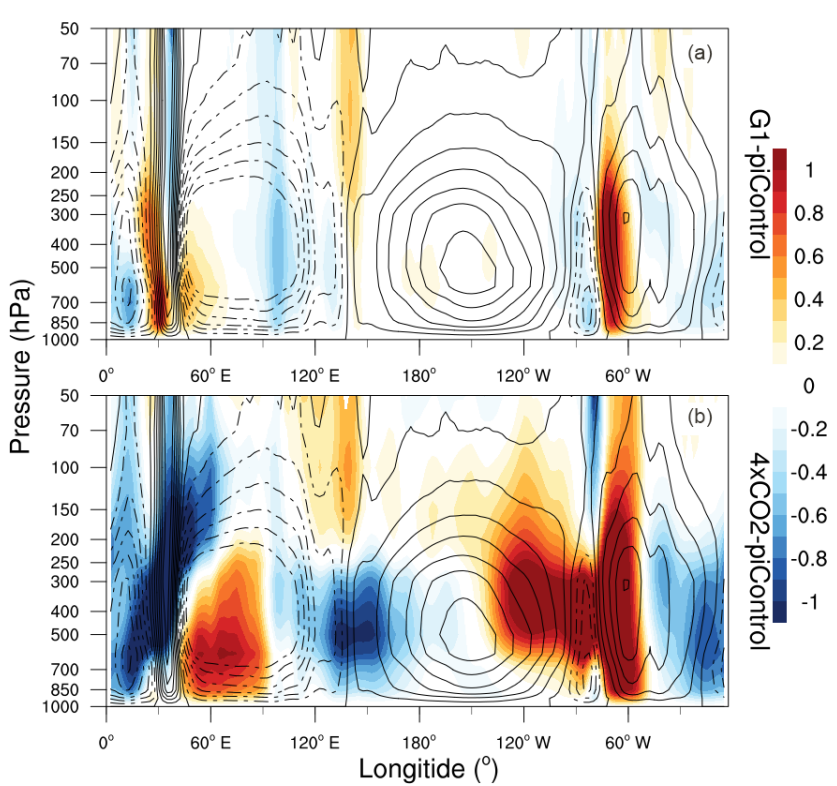

Figure 2. Shading indicates model ensemble mean zonal stream function anomalies $\left(10^{10} \mathrm{~kg} \mathrm{~s}^{-1}\right) \mathrm{G} 1$-piControl (a) and abrupt4xCO2-piControl (b). Warm colors (positive values) indicate a clockwise rotation and cold colors (negative values) indicate an anticlockwise rotation. Contours indicate the value of averaged meridional mass stream function $\left(10^{10} \mathrm{~kg} \mathrm{~s}^{-1}\right)$ in piControl as plotted in Fig. 1c.

\section{Hadley circulation intensity response}

The climatology of the meridional mass stream function $\left(\psi_{\mathrm{m}}\right)$ calculated from the multi-model ensemble mean is shown in Figs. 4 and 5 and the individual models are shown in Fig. S4. This can naturally describe the $\mathrm{HC}$ with a clockwise rotation in the $\mathrm{NH}$ and an anticlockwise rotation in the Southern Hemisphere (SH). The southern Hadley cell width spans nearly $35^{\circ}$ of latitude and the northern Hadley cell

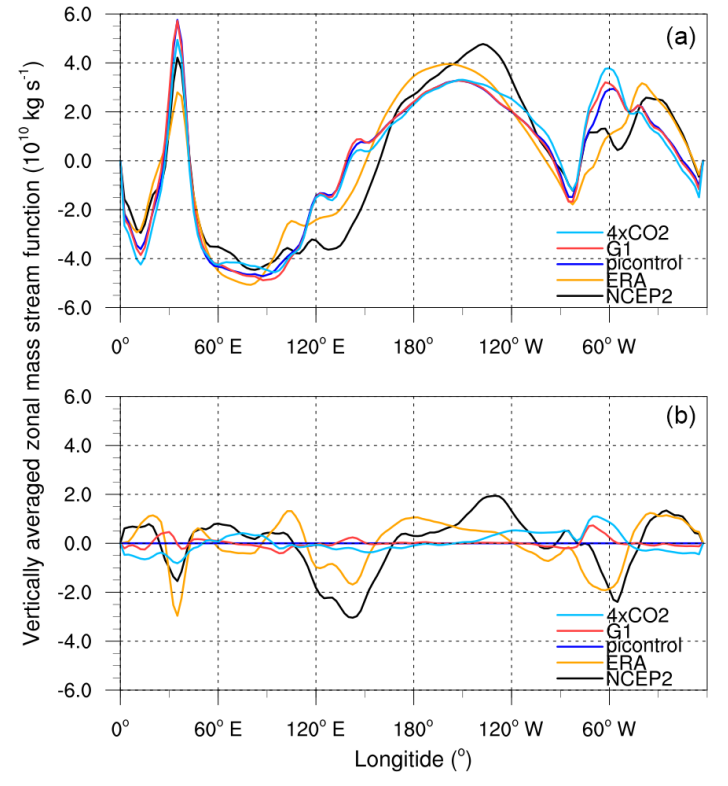

Figure 3. The vertically averaged zonal mass stream function $\left(10^{10} \mathrm{~kg} \mathrm{~s}^{-1}\right)$ (a) in piControl, G1, abrupt $4 \times \mathrm{CO} 2$ experiment for ensemble mean, ERA-Interim and NCEP2; their difference relative to piControl (b).

about $25^{\circ}$ of latitude. The intensity anomalies relative to piControl from both the reanalysis data sets are less than $21 \%$ (Fig. 4).

Circulation anomalies under abrupt4xCO2 (Fig. 5b) show enhanced overturning aloft and weakened overturning at lower levels in both northern and southern Hadley cells. The elevation of the circulation upper branches rises with increased GHG concentration, as previously noted (Vallis et al., 2015), and is likely a consequence of the rise in tropopause height due to GHGs. The southern cell shows a complex anomaly structure with a positive anomaly between 45 and 


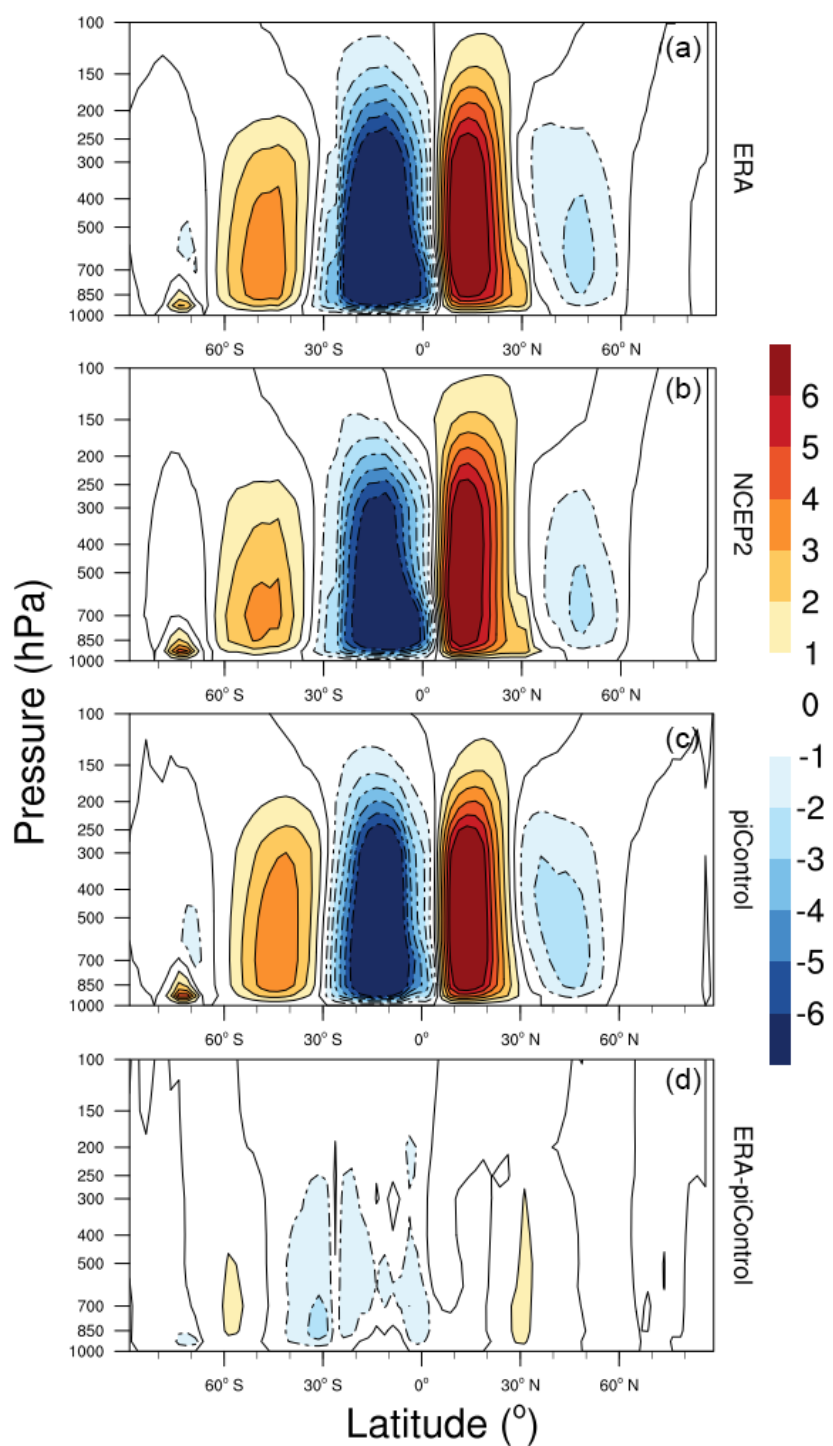

Figure 4. Hadley circulation in the ERA-Interim reanalysis (a), NCEP2 reanalysis (b), model ensemble mean under piControl (c) and the difference between ERA-Interim and piControl (d). Color bar indicates the value of averaged meridional mass stream function $\left(10^{10} \mathrm{~kg} \mathrm{~s}^{-1}\right)$. Warm colors (positive values) indicate a clockwise rotation and cold colors (negative values) indicate an anticlockwise rotation.

$65^{\circ} \mathrm{S}$ also in the Ferrel cell circulation that borders it at higher southern latitudes. The northern cell anomaly is simpler in comparison. Under G1 the changes (Fig. 5a) are largest near the equatorial margins of the cells, with a clear increase in the strength of the ascending current. There is no significant change in the upper branch of the circulation, showing that the tropopause has returned to close to piControl conditions despite the greenhouse concentrations being raised. Seasonal differences illustrate the changes induced under the experiments in a clearer way than the annual ensemble result (Fig. 6).

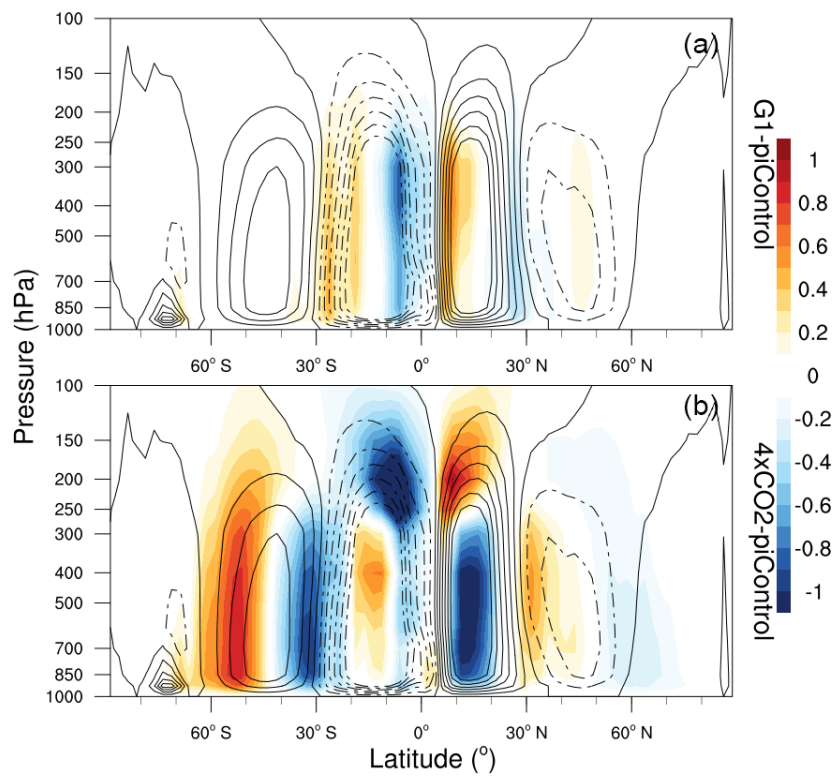

Figure 5. Shading indicates model ensemble mean zonal stream function anomalies $\left(10^{10} \mathrm{~kg} \mathrm{~s}^{-1}\right) \mathrm{G} 1$-piControl (a) and abrupt4xCO2-piControl (b). Warm colors (positive values) indicate a clockwise rotation and cold colors (negative values) indicate an anticlockwise rotation. Contours indicate the value of averaged meridional mass stream function $\left(10^{10} \mathrm{~kg} \mathrm{~s}^{-1}\right)$ in piControl as plotted in Fig. 4c.

In JAS, when the ITCZ is located furthest north around $15^{\circ} \mathrm{N}$, the G1 anomaly indicates a reduction in the upward branch of the southern cell or, equivalently, a southern migration of the ITCZ. Similarly in JFM there is a corresponding reduction in the strength of the upwelling branch of the northern cell (Fig. 6c and d). This is a similar result as obtained by Smyth et al. (2017), who considered the ITCZ position to be defined as the centroid of precipitation and found changes in position of fractions of a degree. Figure $7 \mathrm{~b}$ shows that the modeled motion of the ITCZ explains $73 \%$ of the variance in intensity of the JAS southern cell peak intensity, which is significant at the $95 \%$ level. Thus the larger the model reduction in intensity, the more the boundary of the ITCZ moves equatorward. The correlation for the JFM northern cell (Fig. 7a) is not strong enough to be significant, though it still indicates correlation between intensity and ITCZ position changes. The combined seasonal effect of both cell changes is a reduced migration of the upwelling branches of the circulation cells across the Equator, as was also noted by Smyth et al. (2017).

The GISS-E2-R model has strikingly different anomalies under both $\mathrm{G} 1$ and abrupt $4 \mathrm{xCO} 2$ compared with other models, with much more variability and more changes in the sign of rotation not only within the Hadley cell but also in the surrounding Ferrel cells. If we exclude this model from the ensemble, we get an even clearer result showing that the move- 

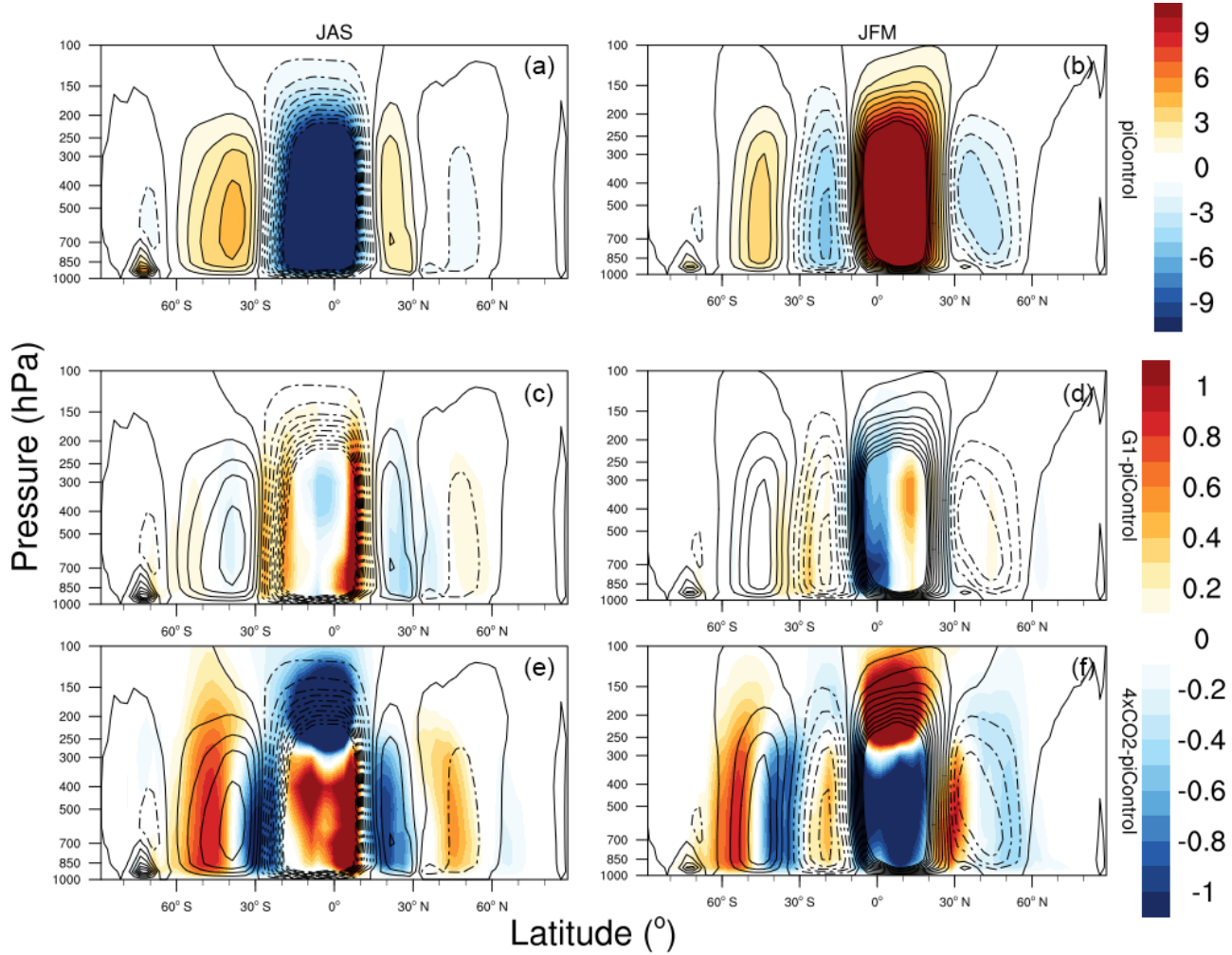

Figure 6. Model ensemble mean meridional stream function in piControl (a, b), anomalies relative to piControl for G1 (c, d) and anomalies relative to piControl for abrupt4xCO2 experiments (e, f). Panels (a, $\mathbf{c}, \mathbf{e})$ indicate JAS months and panels (b, d, f) indicate JFM months. Color bar indicates the value of averaged meridional mass stream function $\left(10^{10} \mathrm{~kg} \mathrm{~s}^{-1}\right)$. Warm colors (positive values) indicate a clockwise rotation and cold colors (negative values) indicate an anticlockwise rotation. Contours indicate the value of averaged meridional mass stream function $\left(10^{10} \mathrm{~kg} \mathrm{~s}^{-1}\right)$ in piControl.

ment of the equatorial edge of the Hadley cells (the ITCZ) totally dominates the response under G1 (Fig. S5).

The situation under abrupt $4 \mathrm{xCO} 2$ is more complex (Fig. 6e and f). The expansion of the tropics has been noted both in GHG simulations and observationally (Davis et al., 2016; Hu et al., 2011), along with the larger southern expansion. The extratropical changes in the Ferrel circulation are also more pronounced in the $\mathrm{SH}$.

A reduction in the strength of the $\mathrm{NH}$ winter cell was also a robust result of climate models under RCP8.5, while the southern cell exhibited almost no change (Vallis et al., 2015). Our results in Fig. 8 show a multi-model ensemble mean reduction of Hadley intensity under G1 of $-18 \times 10^{8}$ and of $-7 \times 10^{8} \mathrm{~kg} \mathrm{~s}^{-1}$ for abrupt $4 \mathrm{xCO} 2$. The JAS southern Hadley intensity exhibits a fall of $-16 \times 10^{8} \mathrm{~kg} \mathrm{~s}^{-1}$ under G1 but an increase of $23 \times 10^{8} \mathrm{~kg} \mathrm{~s}^{-1}$ under abrupt $4 \times \mathrm{CO} 2$. At least six out of eight models agree on these sign changes in both hemispheres and scenarios. Thus the $\mathrm{SH}$ results differ for abrupt $4 \mathrm{xCO} 2$ from those presented in Vallis et al. (2015). The anomalies for most models are significant, and the ensemble means are 8 standard errors from zero and thus highly significant.

\section{ENSO variability in the Walker and Hadley circulations}

Many previous study have concluded that the WC weakens and shifts eastward during El Niño, with opposite effects under La Niña (Ma and Zhou, 2016; Power and Kociuba, 2011; Yu et al., 2012; Power and Smith, 2007). HC shrinks and strengthens during El Niño events, while expanding and weakening during La Niña (Nguyen et al., 2013; Stachnik and Schumacher, 2011). The G1 solar dimming SRM impacts on the Walker and Hadley circulations during ENSO events will be discussed in this section.

The WC differences between $\mathrm{G} 1$, abrupt $4 \mathrm{xCO} 2$ and piControl vary among models during ENSO events (Fig. S6). But the multi-model ensemble mean presents a clear picture (Fig. 9). The results show that features of the WC response to ENSO are significantly changed under abrupt $4 \mathrm{xCO} 2 \mathrm{com}-$ pared with piControl, while G1 compares quite closely to piControl. Differences between G1 and piControl only manifest themselves at the eastern (about $165-180^{\circ} \mathrm{E}$ ) and western (about $120-90^{\circ} \mathrm{W}$ ) sides of the $\mathrm{WC}$, with a significant westward movement during El Niño and no significant changes during La Niña. 


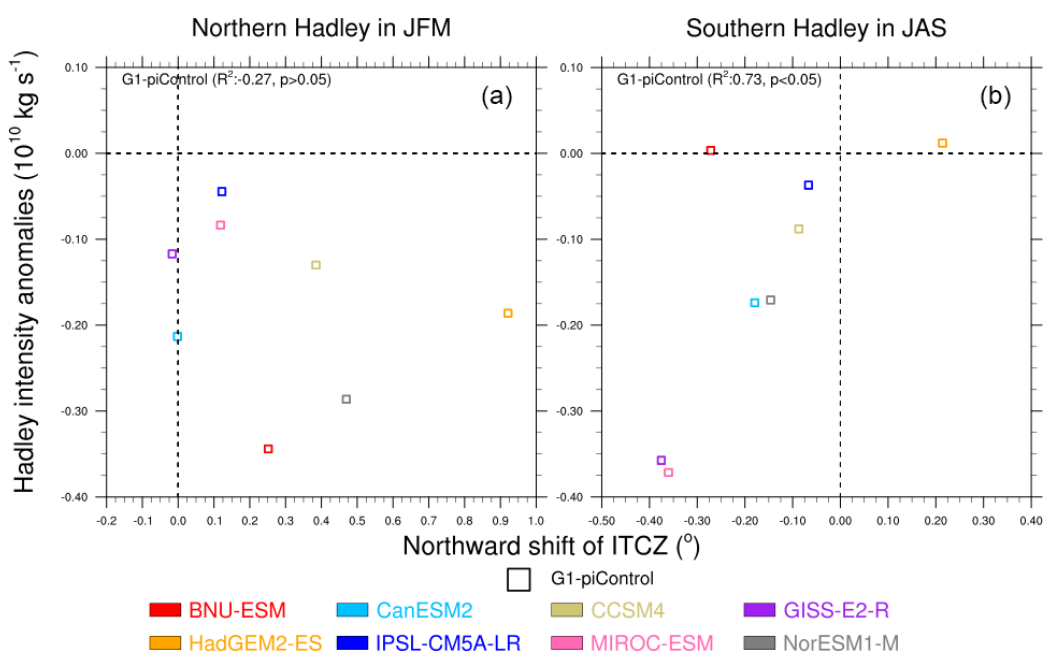

Figure 7. Change in Hadley cell intensity as a function of ITCZ position under G1 relative to piControl across the models for the northern Hadley cell in JFM (a) and the southern Hadley cell in JAS (b). The ITCZ position is defined from the centroid of precipitation (Smyth et al., 2017).

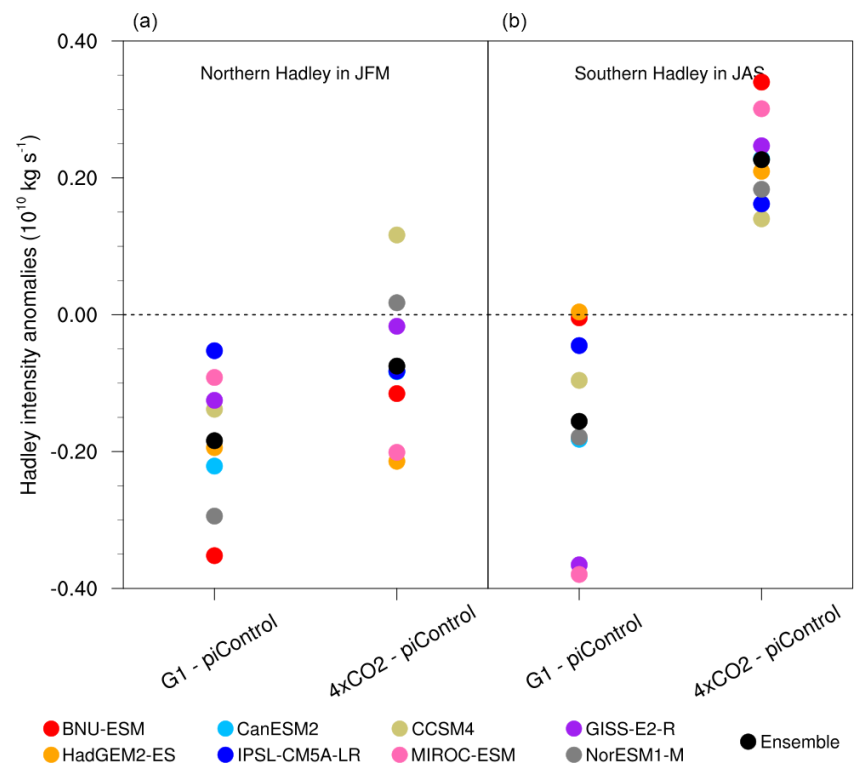

Figure 8. Anomalies $\left(10^{10} \mathrm{~kg} \mathrm{~s}^{-1}\right)$ relative to piControl amongst models in Hadley circulation for the northern cell in JFM (a), defined as the magnitude of the mean meridional stream function between $15^{\circ} \mathrm{S}$ and $40^{\circ} \mathrm{N}$, and (b) the southern cell in JAS, defined as the magnitude of the mean meridional stream function between $15^{\circ} \mathrm{N}$ and $40^{\circ} \mathrm{S}$. The dot size for the models is about 1 standard error of the model mean.

In contrast, under abrupt $4 \mathrm{xCO} 2$ almost the whole $\mathrm{WC}$ (about $165^{\circ} \mathrm{E}-105^{\circ} \mathrm{W}$ ) strengthens in intensity and the western edge shifts westward at the $95 \%$ statistical significance level during El Niño relative to piControl. During La Niña there is a significant eastward movement in general.
$\mathrm{HC}$ responses to ENSO under $\mathrm{G} 1$, abrupt $4 \mathrm{xCO} 2$ and piControl vary among models (Fig. S7). Figure 10 shows the ensemble mean results. As with the WC, the climatological features of the Hadley cell show more significant changes under abrupt $4 \mathrm{xCO} 2$ than $\mathrm{G} 1$ compared with piControl.

The most notable feature of Fig. 10 is the increase in intensity during La Niña between $10^{\circ} \mathrm{S}$ and $10^{\circ} \mathrm{N}$ under abrupt $4 \mathrm{xCO} 2$. This corresponds to changes in the southern Hadley cell (remember that the axis of the Hadley cells is northwards of the Equator). Also under the same conditions there is weakening of the northern Hadley cell between 10 and $20^{\circ} \mathrm{N}$. The same features are almost as noticeable for abrupt $4 \mathrm{xCO} 2$ for El Niño conditions and hence is a general feature of the abrupt $4 \mathrm{xCO} 2$ climate state. Beyond the Hadley cells there are modest but statistically significant changes in the Ferrel circulations, particularly in the SH. Changes under G1 in comparison are much smaller than under abrupt $4 \mathrm{xCO} 2$, though there are significant reductions in intensity near the margins of the Hadley cells. The northern cell is more affected in El Niño, while the southern one is more affected in La Niña states.

\section{Hadley and Walker circulations relationships with temperature}

\subsection{Walker circulation}

Changes in tropical Pacific SST dominate the global warming response of the WC change (Sandeep et al., 2014). A reduced SST gradient between the eastern and western $\mathrm{Pa}$ cific drives the weakening of the $\mathrm{WC}$ that was seen in a quadrupled $\mathrm{CO}_{2}$ experiment (Knutson and Manabe, 1995). The temperature difference between the eastern and west- 


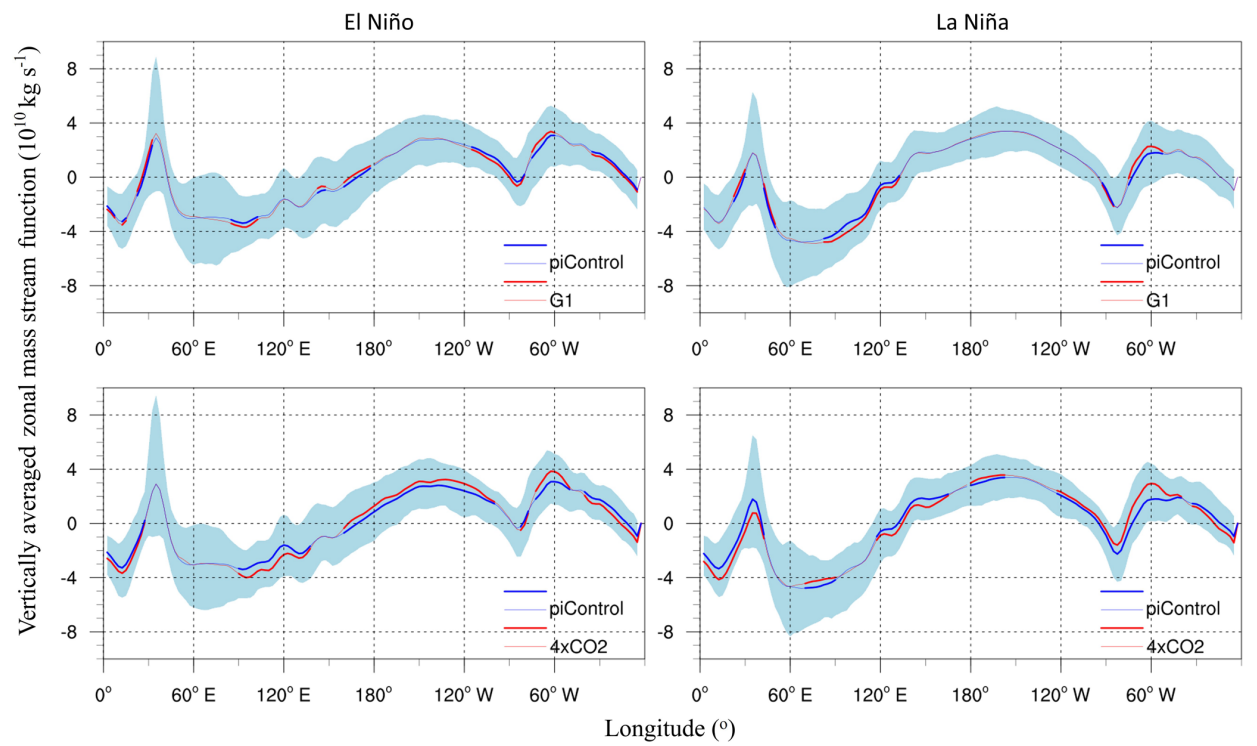

Figure 9. The vertically averaged zonal mass stream function under ENSO. For El Niño or La Niña conditions, the blue line in each panel represents the vertically averaged zonal mass stream function $\left(10^{10} \mathrm{~kg} \mathrm{~s}^{-1}\right)$ under piControl. The red line in the top row is $\mathrm{G} 1$ and the bottom row is abrupt $4 \times \mathrm{xO} 2$. The thick lines denote locations where circulation changes are significant at the $95 \%$ confidence level. The $16-84 \%$ range across the eight individual models is shown by light blue shading.

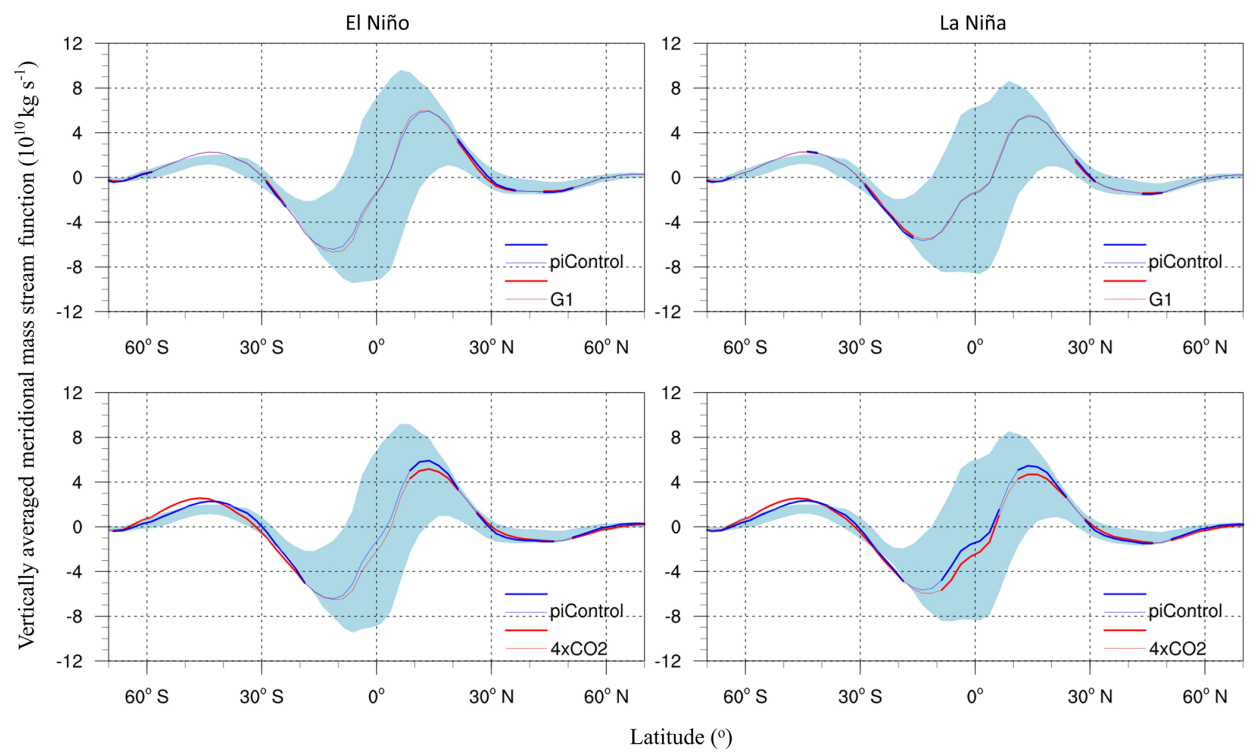

Figure 10. The vertically averaged meridional mass stream function under ENSO. For El Niño or La Niña conditions, the blue line in each panel represents the vertically averaged zonal mass stream function $\left(10^{10} \mathrm{~kg} \mathrm{~s}^{-1}\right)$ under piControl. The red line in the top row is G1 and the bottom row is abrupt $4 \mathrm{xCO} 2$. The thick lines denote locations where circulation changes are significant at the $95 \%$ confidence level. The $16-84 \%$ range across the eight individual models is shown by light blue shading.

ern Pacific SST explains $96 \%$ of the inter-model variance in the strength of the WC in the G1-piControl anomalies and $79 \%$ of the variance for abrupt $4 \mathrm{xCO} 2$-piControl (Fig. 11). There is no difference in model behavior between the G1 and abrupt $4 \mathrm{xCO} 2$ anomalies and SST explains $83 \%$ of the overall variance. Despite a temperature transient of a decade or so (e.g., Kravitz et al., 2013) in the abrupt $4 \mathrm{xCO} 2$ simulation and the lack of any transient in STRF (Fig. S1), the relationship with $\Delta$ SST is nearly as good as for piControl. This suggests that there is no difference in the mode of behavior of the WC under solar dimming SRM or GHG forcing in contrast to the changes seen in the Hadley cells.

The correlation between yearly STRF and global $2 \mathrm{~m}$ temperatures is shown in Fig. 12 and the individual models are 

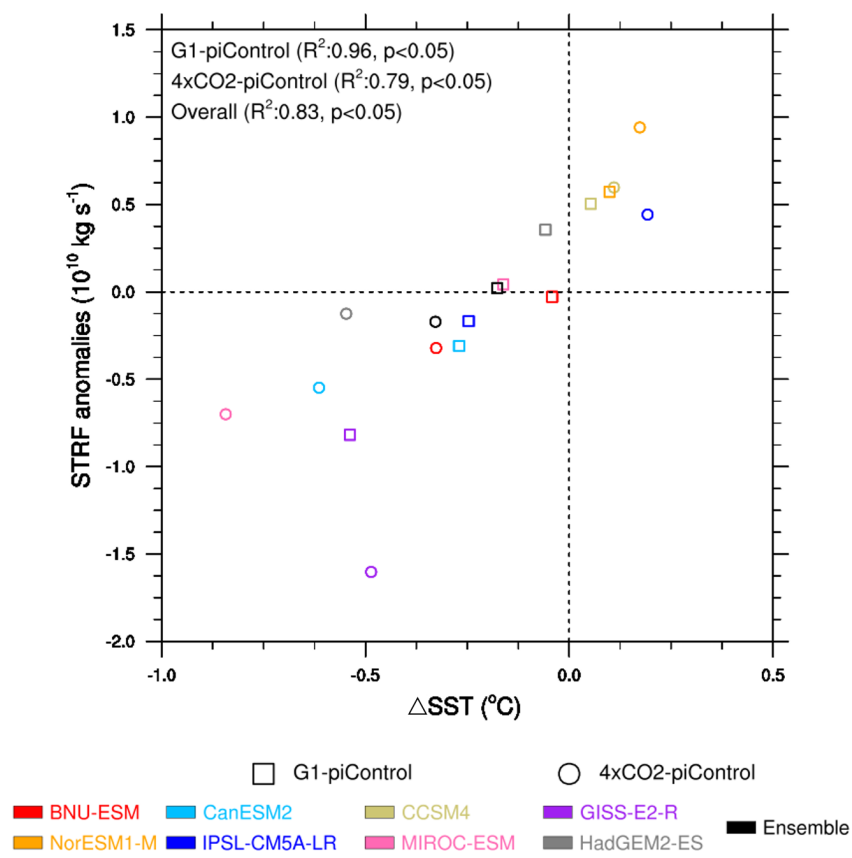

Figure 11. Model mean monthly anomalies relative to each model's piControl of STRF and $\triangle \mathrm{SST}$. A positive value of STRF and $\triangle \mathrm{SST}$ indicates strengthening of the Walker circulation.

shown in Fig. S8. We discard the first 20 years for G1 and abrupt $4 \mathrm{xCO} 2$ to remove the temperature transients. In G1 all models except CanESM2 and MIROC-ESM have strong negative correlations between STRF and tropical Pacific temperatures. BNU-ESM, CCSM4 and NorESM1-M show a positive correlation with temperatures in the South Pacific convergence zone (SPCZ) and its linear extension in the South Atlantic. These features are generally muted or absent in the piControl simulations. Experiments with an atmospheric circulation model (Van der Wiel et al., 2016) suggest that a key feature of the diagonal structure of the SPCZ is the zonal temperature gradient in the Pacific, which allows warm moist air from the Equator into the SPCZ region. This moisture then intensifies (diagonal) bands of convection carried by Rossby waves (Van der Wiel et al., 2016). Two of the three models with a positive correlation between STRF and SPCZ temperatures, CCSM4 and NorESM1-M, have increased STRF and $\triangle$ SST under G1 (Fig. 11), suggesting that this mechanism is responsive in at least some of the models to G1 changes in forcing. The SPCZ is the only part of the ITCZ that extends beyond the tropics and so may be expected to be more subject to the meridional gradients in radiative forcing produced by $\mathrm{G} 1$. The correlations under abrupt $4 \mathrm{xCO} 2$ are more variable across the models, though some of the models like IPSL-CM5A-LR, MIROC-ESM and HadGEM2-ES exhibit widespread anticorrelation between STRF and temperatures; the spatial variability suggests that this is not due to the strong transient response in global temperature rises under abrupt $4 \mathrm{xCO} 2$.

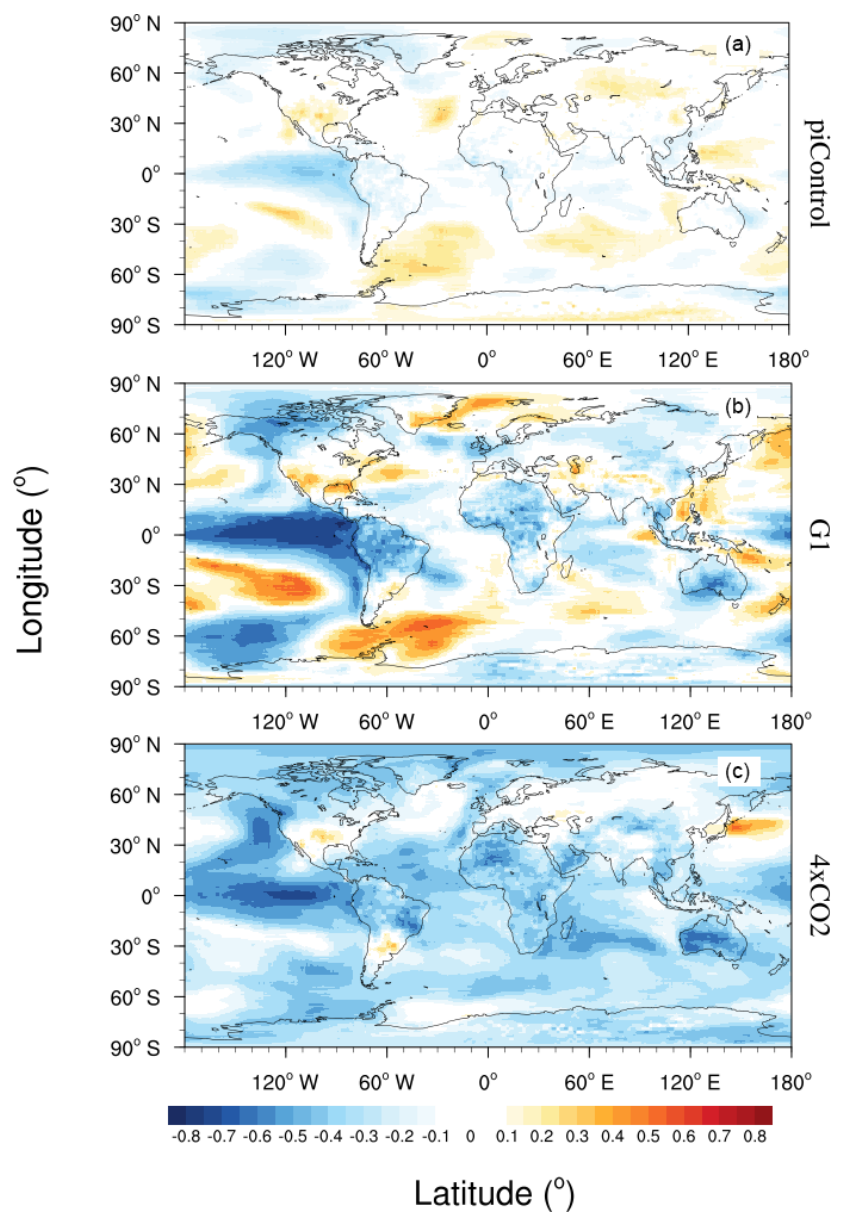

Figure 12. Mean correlation between yearly STRF and global gridded $2 \mathrm{~m}$ temperatures for 100 years of piControl (a) and the final 30 years of $\mathrm{G} 1$ (b) and abrupt4xCO2 (c) experiments for the eightmodel ensemble mean.

\subsection{Hadley circulation}

We now consider how surface temperature changes may impact the HC. To remove the transients, we only use the last 30 years for $\mathrm{G} 1$ and abrupt $4 \mathrm{xCO} 2$. The decrease in the northern Hadley cell intensity in JFM (Fig. 8) correlates with northern hemispheric land temperatures (Fig. 13), explaining $58 \%$ of the variance in model anomaly under G1 - which is nevertheless not significant at the $95 \%$ level - and $81 \%$ under abrupt $4 \mathrm{xCO} 2$. NH land temperature also explains $83 \%$ of the G1 anomaly in the southern Hadley cell in JAS, but has no impact on the abrupt $4 \mathrm{xCO} 2$ anomaly. Both SRM and GHG forcing modifies the land-ocean temperature difference relative to piControl and so conceivably affects $\mathrm{HC}$, for example by changing the hemispheric temperature and the position of the ITCZ (Broccoli et al., 2006). Under abrupt $4 x \mathrm{xO} 2$, landocean temperature differences in the tropics (between $30^{\circ} \mathrm{N}$ and $30^{\circ} \mathrm{S}$ ) are reduced to essentially zero, while under G1 differences in the tropics are $1.2^{\circ} \mathrm{C}$, which is not significantly 


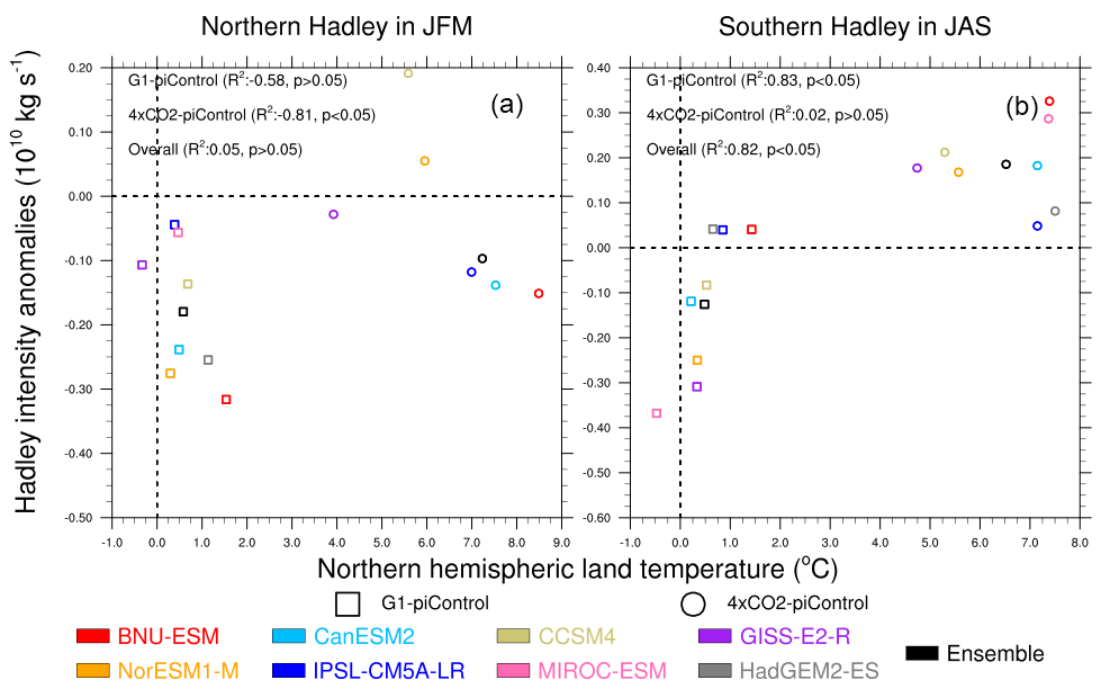

Figure 13. Hadley intensity mean model anomalies versus the Northern Hemisphere land temperature for the northern Hadley cell in JFM (a) and the southern Hadley cell in JAS (b). A positive value of Hadley intensity indicates Hadley circulation strengthening regardless of the direction.

different from the piControl difference of $1.4^{\circ} \mathrm{C}$. Since the largest continental land masses are in the $\mathrm{NH}$, we would expect any differences in $\mathrm{HC}$ induced by land-ocean contrasts in the NH to be visible in the southern Hadley cell. We explored the impact of land-ocean temperature differences by considering differences in the surface temperatures over Tibet and the whole tropical ocean temperature (Fig. S9). Results were similar to those for Fig. 13, with significant correlations for G1 in the southern Hadley cell.

Seo et al. (2014) examine the relative importance of changes in meridional temperature gradients in potential temperature, subtropical tropopause height and static stability on the strength of the HC. They find that according to scaling theory based on the Held and Hou (1980) and the Held (2000) models and an analysis of 30 CMIP5 models forced by the RCP 8.5 scenario, the meridional temperature gradient is the most important factor.

We used the same procedure as Seo et al. (2014) on the four models (BNU-ESM, IPSL-CM5A-LR, HadGEM2-ES, MIROC-ESM) that provide all the fields needed under the G1 and abrupt $4 \times \mathrm{xCO} 2$ scenarios (Table 3). The changes in ensemble mean circulation intensity are similar under G1 and abrupt $4 \mathrm{xCO} 2$, as are the changes in potential temperature gradients relative to piControl, but the changes in static stability are very different between the experiments. The tropospheric heights also change between $\mathrm{G} 1$ and abrupt $4 \mathrm{xCO} 2$ scenarios, with small reductions under G1 and about a 3 and $0.9 \%$ increase, respectively, in the southern and northern cells under abrupt $4 \mathrm{xCO} 2$. We used the two scaling relations given by Seo et al. (2014) to also estimate the change in Hadley intensity based on the changes in temperature gradients, static stability and tropospheric height for the ensemble mean of the four models (Table 3). Both formula- tions give fairly similar numbers for the estimated change in Hadley intensities in the northern and southern cells under $\mathrm{G} 1$ and abrupt $4 \mathrm{xCO} 2$. These estimates agree with the simulated changes in intensities under G1, but are very different from those simulated under abrupt $4 \mathrm{xCO} 2$. The obvious cause of the discrepancies under abrupt $4 \mathrm{xCO} 2$ is the change in static stability, which in both model scaling formulations leads to $18-25 \%$ reductions in Hadley intensity compared with the ensemble model simulated changes of about $\pm 4 \%$. This supports the analysis of Seo et al. (2014) that it is the meridional temperature gradient that is the dominant factor in determining the strength of the $\mathrm{HC}$.

\section{Discussion}

He and Soden (2015) conclude from experiments designed to elucidate the role of various forcings on tropical circulation that weakening of the WC under GHG forcing is primarily due to mean SST warming. They also note that increased land-sea temperature contrast results in strengthening of the circulation, and also that while the pattern of GHG warming is close to an El Niño, there are sufficient differences to produce quite different responses in the WC. We may therefore expect that changes under G1 compared with pure GHG forcing would manifest themselves given the changes in both the direct and indirect $\mathrm{CO}_{2}$ forcings. What we observe, though, is that changes in the WC are modest, and examination of the dependence on intensity as a function of zonal Pacific Ocean temperature differences (Fig. 11) shows no differences between the GHG and G1 forcings. Similarly, we find no change in the intensity with land-ocean temperature gradients. 
ent plays the dominant role rather than tropopause height or static stability changes.

Grise and Polvani (2016) explored how the dynamic response of the atmosphere, including metrics such as Hadley cell edge, varied with model climate sensitivity, which is the mean temperature rise associated with doubled $\mathrm{CO}_{2}$. They found significant correlation across a suite of CMIP5 models running the abrupt $4 \mathrm{xCO} 2$ that was largely confined to the $\mathrm{SH}$ and also that the pole-to-Equator surface temperature gradient accounted for significant parts of the dynamic variability that was not dependent on the mean temperature. However, we find that the response times of the HCs to changes in radiative forcing are very fast, as shown by the lack of transients in the simulated time series. Sea surface temperatures, especially under the strong abrupt $4 \mathrm{xCO} 2$ forcing, takes at least a decade and parts of the system, such as the deeper ocean, would require even longer to reach equilibrium. Under abrupt $4 \mathrm{xCO} 2$ the global land-ocean temperature difference is reduced by about $1.3^{\circ} \mathrm{C}$ relative to piControl, while G1 reduces the contrast by only $0.3^{\circ} \mathrm{C}$. The $\mathrm{NH}$ continents have faster response times than the oceans and so we would expect the $\mathrm{SH}$ to be much further from an equilibrium response than the NH. This is also reflected in the lack of an equivalent to the "Arctic amplification" seen in the NH under both observed and simulated forcing by GHGs. The lack of anomalous southern polar warming is linked to the much cooler surface temperatures in the Antarctic mitigating both temperature feedbacks and the ice-albedo feedback mechanism (Pithan and Mauritsen, 2014). The speed of the response of the circulation changes calls into question the importance of static stability and meridional gradients in driving the changes in the circulation, since the circulation responds faster. Bony et al. (2013) attributed rapid changes in circulation in quadrupled $\mathrm{CO}_{2}$ to direct $\mathrm{CO}_{2}$ forcing. A fast response could also be a result of cloud feedback, land-ocean temperature differences and perhaps humidity, which are also important for poleward energy transport in G1 (Russotto and Ackerman, 2018a, b). The low cloud fraction decreases under G1, warming the planet by reducing the reflection of solar shortwave radiation, but atmospheric humidity is reduced, allowing heat to escape, and less energy is transported from the tropics to the poles.

Our analysis of circulation intensity changes and their dependence on temperature changes shows quite different sets of behavior under $\mathrm{G} 1$ than under abrupt $4 \mathrm{xCO} 2$ for the Hadley but not the WC. The response under G1 relative to piControl is a slight overcooling of the tropics relative to the global mean temperature (Kravitz et al., 2013). Experiments with idealized climate models (Tandon et al., 2013) show that heating at the Equator alone tends to reduce the Hadley cell width, while wider heating in an annulus around the outer tropics $\left(20-35^{\circ}\right.$ in each hemisphere) tends to produce a complex response to circulation in both Hadley and Ferrel cells more reminiscent of the anomaly patterns seen under abrupt $4 \mathrm{xCO} 2$. The climate forcing under $\mathrm{G} 1$ is de- signed to be zonally symmetric, and that may explain the lack of impact in the WC under both G1 and GHG forcing. There are clear changes in Hadley cells under the latitudinal varying forcing of G1. The reduction in incoming shortwave radiation in G1 would intuitively mean reduced heating, sea surface temperatures and moisture flux in the ITCZ, which follows the movement of the sun. Analysis of extreme precipitation events in daily data from the GeoMIP models (Ji et al., 2018) shows that the annual wettest consecutive 5 days are drier under G1 along a seasonal path that follows the ITCZ motion, while precipitation extremes increase in the tropical dry seasons. This result is consistent with the variation in the Hadley intensity cell seen here.

\section{Summary}

Our main purpose in this study has been to answer the following questions: does the G1 scenario counteract the position and intensity variations in the Walker and Hadley circulations caused by the GHG longwave forcing under abrupt $4 \mathrm{xCO} 2$ ? How does the tropical atmospheric circulation, including the Walker and Hadley circulations, respond to warm and cold phases of the El Niño-Southern Oscillation (ENSO) in G1 and abrupt $4 \mathrm{xCO} 2$ ?

The WC in G1 displays insignificant increases in intensity and no shift in its western edge in the Pacific Ocean relative to piControl and hence does counteract the changes from GHG forcing. There is a potentially important change in the position of the WC associated with the West African rain forest and East African grassland zones under G1, with potential for the encroachment of a drier climate into the Congo basin. In contrast, the $\mathrm{HC}$ shows larger changes under G1 that are not simple reversals of those induced by GHG forcing on piControl climate. There are asymmetric responses between the hemispheres under both GHG and solar dimming that are correlated with direct forcings rather than adjustment of sea surface temperatures and correlated with changes in meridional and land-ocean temperature gradients. These differences in the response of the Hadley and Walker circulations are consistent with the zonally invariant forcing of both solar dimming and GHGs and the meridionally varying solar dimming.

A clear WC westward movement during El Niño and an eastward movement during La Niña are shown nearly everywhere along the Equator in abrupt $4 \mathrm{xCO} 2$. However, the eastern and western boundaries of the WC shift westward during El Niño in G1 relative to piControl. The range and amplitudes of significant changes are smaller in G1 than in abrupt $4 \mathrm{xCO} 2$. The same is true in general for the Hadley cell. Under abrupt $4 \mathrm{xCO} 2$ the northern Hadley cell significantly decreases in intensity under both la Niña and El Niño conditions, while under G1 the decreases are smaller and limited to each cell's poleward boundaries. 
Both models and the limited observational data available on the $\mathrm{HC}$ indicate that it is not zonally symmetric: there are intense regions of circulation at the eastern sides of the oceanic basins (Karnauskas and Ummenhofer, 2014), while elsewhere circulation is reversed, and much of the natural variability of the circulation is related to ENSO (Amaya et al., 2017). This and the opposite correlations with surface temperatures in the Pacific and SPCZ with STRF under G1 (Fig. 12) suggest an interplay between the $\mathrm{HC}$ and WC that could justify further consideration of model data at seasonal scales. The importance of the tropical ocean basins as genesis regions for intense storms also suggests that changed radiative forcing there under SRM could cause important differences in seasonal precipitation extremes that may be hidden in monthly or annual data sets.

Data availability. The raw G1 data are archived at https: //esgf-data.dkrz.de/search/esgf-dkrz/ (last access: 17 June 2018), and the raw piControl and abrupt $4 \mathrm{xCO} 2$ data are archived at both https://esgf-data.dkrz.de/search/esgf-dkrz/ and http://www. ipcc-data.org/sim/gcm_monthly/AR5/Reference-Archive.html (last access: 17 June 2018). The CCSM4 model data are archievd at https://www.earthsystemgrid.org/search.html?freeText= GeoMIP\&Project=GeoMIP (last access: 17 June 2018). The CanESM2, GISS-E2-R and NorESM1-M data are archived by the modeling team.

Supplement. The supplement related to this article is available online at: https://doi.org/10.5194/acp-18-8689-2018-supplement.

Competing interests. The authors declare that they have no conflict of interest.

Special issue statement. This article is part of the special issue "The Geoengineering Model Intercomparison Project (GeoMIP): Simulations of solar radiation reduction methods (ACP/GMD interjournal SI)". It is not associated with a conference.

Acknowledgements. We thank two anonymous referees for very constructive comments, the climate modeling groups for participating in the Geoengineering Model Intercomparison Project and their model development teams, the CLIVAR/WCRP Working Group on Coupled Modeling for endorsing the GeoMIP, and the scientists managing the Earth system grid data nodes who have assisted with making GeoMIP output available. This research was funded by the National Basic Research Program of China (grant 2015CB953600).

Edited by: Ben Kravitz

Reviewed by: two anonymous referees

\section{References}

Amaya, D. J., Siler, N., Xie, S.-P., and Miller, A. J.: The interplay of internal and forced modes of Hadley Cell expansion: lessons from the global warming hiatus, Clim. Dynam., 1-15, 2017.

Arora, V. K., Scinocca, J. F., Boer, G. J., Christian, J. R., Denman, K. L., Flato, G. M., Kharin, V. V., Lee, W. G., and Merryfield, W. J.: Carbon emission limits required to satisfy future representative concentration pathways of greenhouse gases, Geophys. Res. Lett., 38, L05805, https://doi.org/10.1029/2010GL046270, 2011.

Bala, G., Caldeira, K., Nemani, R., Cao, L., Ban-Weiss, G., and Shin, H. J.: Albedo enhancement of marine clouds to counteract global warming: impacts on the hydrological cycle, Clim. Dynam., 37, 915-931, 2011.

Bayr, T., Dommenget, D., Martin, T., and Power, S. B.: The eastward shift of the Walker Circulation in response to global warming and its relationship to ENSO variability, Clim. Dynam., 43, 2747-2763, 2014.

Bentsen, M., Bethke, I., Debernard, J. B., Iversen, T., Kirkevåg, A., Seland, Ø., Drange, H., Roelandt, C., Seierstad, I. A., Hoose, C., and Kristjánsson, J. E.: The Norwegian Earth System Model, NorESM1-M - Part 1: Description and basic evaluation of the physical climate, Geosci. Model Dev., 6, 687-720, https://doi.org/10.5194/gmd-6-687-2013, 2013.

Bjerknes, J.: Atmospheric teleconnections from the equatorial Pacific, Mon. Weather Rev., 97, 163-172, 1969.

Bony, S., Bellon, G., Klocke, D., Sherwood, S., Fermepin, S., and Denvil, S.: Robust direct effect of carbon dioxide on tropical circulation and regional precipitation, Nat. Geosci., 6, 447-451, 2013.

Broccoli, A. J., Dahl, K. A., and Stouffer, R. J.: Response of the ITCZ to Northern Hemisphere cooling, Geophys. Res. Lett., 33, L01702, https://doi.org/10.1029/2005GL024546, 2006

Choi, J., Son, S. W., Lu, J., and Min, S. K.: Further observational evidence of Hadley cell widening in the Southern Hemisphere, Geophys. Res. Lett., 41, 2590-2597, 2014.

Collins, W. J., Bellouin, N., Doutriaux-Boucher, M., Gedney, N., Halloran, P., Hinton, T., Hughes, J., Jones, C. D., Joshi, M., Liddicoat, S., Martin, G., O’Connor, F., Rae, J., Senior, C., Sitch, S., Totterdell, I., Wiltshire, A., and Woodward, S.: Development and evaluation of an Earth-System model - HadGEM2, Geosci. Model Dev., 4, 1051-1075, https://doi.org/10.5194/gmd-4-10512011, 2011.

Davis, N. A.: The Dynamics of Hadley Circulation Variability and Change, Colorado State University, Libraries, 2017.

Davis, N. A. and Birner, T.: On the Discrepancies in Tropical Belt Expansion between Reanalyses and Climate Models and among Tropical Belt Width Metrics, J. Climate, 30, 1211-1231, 2017.

Davis, N. A., Seidel, D. J., Birner, T., Davis, S. M., and Tilmes, S.: Changes in the width of the tropical belt due to simple radiative forcing changes in the GeoMIP simulations, Atmos. Chem Phys., 16, 10083-10095, https://doi.org/10.5194/acp-16-100832016, 2016.

DiNezio, P. N., Vecchi, G. A., and Clement, A. C.: Detectability of Changes in the Walker Circulation in Response to Global Warming, J. Climate, 26, 4038-4048, 2013.

Dufresne, J. L., Foujols, M. A., Denvil, S., Caubel, A., Marti, O., Aumont, O., Balkanski, Y., Bekki, S., Bellenger, H., Benshila, R., Bony, S., Bopp, L., Braconnot, P., Brockmann, P., Cadule, 
P., Cheruy, F., Codron, F., Cozic, A., Cugnet, D., de Noblet, N., Duvel, J. P., Ethe, C., Fairhead, L., Fichefet, T., Flavoni, S., Friedlingstein, P., Grandpeix, J. Y., Guez, L., Guilyardi, E., Hauglustaine, D., Hourdin, F., Idelkadi, A., Ghattas, J., Joussaume, S., Kageyama, M., Krinner, G., Labetoulle, S., Lahellec, A., Lefebvre, M. P., Lefevre, F., Levy, C., Li, Z. X., Lloyd, J., Lott, F., Madec, G., Mancip, M., Marchand, M., Masson, S., Meurdesoif, Y., Mignot, J., Musat, I., Parouty, S., Polcher, J., Rio, C., Schulz, M., Swingedouw, D., Szopa, S., Talandier, C., Terray, P., Viovy, N., and Vuichard, N.: Climate change projections using the IPSL-CM5 Earth System Model: from CMIP3 to CMIP5, Clim. Dynam., 40, 2123-2165, 2013.

Ferraro, A. J., Highwood, E. J., and Charlton-Perez, A. J.: Weakened tropical circulation and reduced precipitation in response to geoengineering, Environ. Res. Lett., 9, 014001, https://doi.org/10.1088/1748-9326/9/1/014001, 2014.

Frierson, D. M. W., Lu, J., and Chen, G.: Width of the Hadley cell in simple and comprehensive general circulation models, Geophys. Res. Lett., 34, L18804, https://doi.org/10.1029/2007GL031115, 2007.

Gabriel, C. J. and Robock, A.: Stratospheric geoengineering impacts on El Niño/Southern Oscillation, Atmos. Chem. Phys., 15, 11949-11966, https://doi.org/10.5194/acp-15-11949-2015, 2015.

Garfinkel, C. I., Waugh, D. W., and Polvani, L. M.: Recent Hadley cell expansion: The role of internal atmospheric variability in reconciling modeled and observed trends, Geophys. Res. Lett., 42, 10824-10831, 2015.

Gent, P. R., Danabasoglu, G., Donner, L. J., Holland, M. M., Hunke, E. C., Jayne, S. R., Lawrence, D. M., Neale, R. B., Rasch, P. J., Vertenstein, M., Worley, P. H., Yang, Z. L., and Zhang, M. H.: The Community Climate System Model Version 4, J. Climate, 24, 4973-4991, 2011.

Grise, K. M. and Polvani, L. M.: Is climate sensitivity related to dynamical sensitivity?, J. Geophys. Res.-Atmos., 121, 5159-5176, 2016.

He, J. and Soden, B. J.: Anthropogenic Weakening of the Tropical Circulation: The Relative Roles of Direct $\mathrm{CO}_{2}$ Forcing and Sea Surface Temperature Change, J. Climate, 28, 8728-8742, 2015.

Held, I. M.: The general circulation of the atmosphere, in: 2000 Program in Geophysical Fluid Dynamics Proceedings, Woods Hole Oceanographic Institude, Woods Hole, 30-36, 2000.

Held, I. M. and Hou, A. Y.: Nonlinear axially symmetric circulations in a nearly inviscid atmosphere, J. Atmos. Sci., 37, 515533, 1980.

Held, I. M. and Soden, B. J.: Robust responses of the hydrological cycle to global warming, J. Climate, 19, 5686-5699, 2006.

Hu, Y. Y., Zhou, C., and Liu, J. P.: Observational Evidence for Poleward Expansion of the Hadley Circulation, Adv. Atmos. Sci., 28, 33-44, 2011.

Hu, Y. Y., Tao, L. J., and Liu, J. P.: Poleward expansion of the hadley circulation in CMIP5 simulations, Adv. Atmos. Sci., 30, 790$795,2013$.

Iversen, T., Bentsen, M., Bethke, I., Debernard, J. B., Kirkevåg, A., Seland, Ø., Drange, H., Kristjansson, J. E., Medhaug, I., Sand, M., and Seierstad, I. A.: The Norwegian Earth System Model, NorESM1-M - Part 2: Climate response and scenario projections, Geosci. Model Dev., 6, 389-415, https://doi.org/10.5194/gmd-6-389-2013, 2013.
Ji, D., Wang, L., Feng, J., Wu, Q., Cheng, H., Zhang, Q., Yang, J., Dong, W., Dai, Y., Gong, D., Zhang, R.-H., Wang, X., Liu, J., Moore, J. C., Chen, D., and Zhou, M.: Description and basic evaluation of Beijing Normal University Earth System Model (BNU-ESM) version 1, Geosci. Model Dev., 7, 2039-2064, https://doi.org/10.5194/gmd-7-2039-2014, 2014.

Ji, D., Fang, S., Curry, C. L., Kashimura, H., Watanabe, S., Cole, J. N. S., Lenton, A., Muri, H., Kravitz, B., and Moore, J. C.: Extreme temperature and precipitation response to solar dimming and stratospheric aerosol geoengineering, Atmos. Chem. Phys. Discuss., https://doi.org/10.5194/acp-2018-131, in review, 2018.

Johanson, C. M. and Fu, Q.: Hadley Cell Widening: Model Simulations versus Observations, J. Climate, 22, 2713-2725, 2009.

Karnauskas, K. B. and Ummenhofer, C. C.: On the dynamics of the Hadley circulation and subtropical drying, Clim. Dynam., 42, 2259-2269, 2014.

Kanamitsu, M., Ebisuzaki, W., Woollen, J., Yang, S. K., Hnilo, J. J., Fiorino, M., and Potter, G. L.: Ncep-Doe Amip-Ii Reanalysis (R-2), B. Am. Meteorol. Soc., 83, 1631-1643, 2002.

Kang, S. M. and Lu, J.: Expansion of the Hadley Cell under Global Warming: Winter versus Summer, J. Climate, 25, 8387-8393, 2012.

Knutson, T. R. and Manabe, S.: Time-Mean Response over the Tropical Pacific to Increased $\mathrm{CO}_{2}$ in a Coupled OceanAtmosphere Model, J. Climate, 8, 2181-2199, 1995.

Kravitz, B., Robock, A., Boucher, O., Schmidt, H., Taylor, K. E., Stenchikov, G., and Schulz, M.: The Geoengineering Model Intercomparison Project (GeoMIP), Atmos. Sci. Lett., 12, 162167, https://doi.org/10.1002/asl.316, 2011.

Kravitz, B., Caldeira, K., Boucher, O., Robock, A., Rasch, P. J., Alterskjaer, K., Karam, D. B., Cole, J. N. S., Curry, C. L., Haywood, J. M., Irvine, P. J., Ji, D., Jones, A., Kristjánsson, J. E., Lunt, D. J., Moore, J. C., Niemeier, U., Schmidt, H., Schulz, M., Singh, B., Tilmes, S., Watanabe, S., Yang, S., and Yoon, J.-H.: Climate model response from the Geoengineering Model Intercomparison Project (GeoMIP), J. Geophys. Res.-Atmos., 118, 8320-8332, https://doi.org/10.1002/jgrd.50646, 2013.

Lau, W. K. M. and Kim, K. M.: Robust Hadley Circulation changes and increasing global dryness due to $\mathrm{CO}_{2}$ warming from CMIP5 model projections, P. Natl. Acad. Sci. USA, 112, 3630-3635, 2015.

Lu, J., Vecchi, G. A., and Reichler, T.: Expansion of the Hadley cell under global warming, Geophys. Res. Lett., 34, https://doi.org/10.1029/2006GL028443, 2007.

Ma, J. and Xie, S. P.: Regional Patterns of Sea Surface Temperature Change: A Source of Uncertainty in Future Projections of Precipitation and Atmospheric Circulation, J. Climate, 26, 2482-2501, 2013.

Ma, S. M. and Zhou, T. J.: Robust Strengthening and Westward Shift of the Tropical Pacific Walker Circulation during 19792012: A Comparison of 7 Sets of Reanalysis Data and 26 CMIP5 Models, J. Climate, 29, 3097-3118, 2016.

Moore, J. C., Grinsted, A., Guo, X. R., Yu, X. Y., Jevrejeva, S., Rinke, A., Cui, X. F., Kravitz, B., Lenton, A., Watanabe, S., and Ji, D. Y.: Atlantic hurricane surge response to geoengineering, P. Natl. Acad. Sci. USA, 112, 13794-13799, 2015.

Nguyen, H., Evans, A., Lucas, C., Smith, I., and Timbal, B.: The Hadley Circulation in Reanalyses: Climatology, Variability, and 
Change, J. Climate, 26, 3357-3376, https://doi.org/10.1175/jclid-12-00224.1, 2013.

Oort, A. H. and Yienger, J. J.: Observed interannual variability in the Hadley circulation and its connection to ENSO, J. Climate, 9, 2751-2767, 1996.

Pithan, F. and Mauritsen, T.: Arctic amplification dominated by temperature feedbacks in contemporary climate models, Nat. Geosci., 7, 181-184, https://doi.org/10.1038/ngeo2071, 2014.

Power, S. B. and Kociuba, G.: What caused the observed twentiethcentury weakening of the Walker circulation?, J. Climate, 24, 6501-6514, https://doi.org/10.1175/2011JCLI4101.1, 2011.

Power, S. B. and Smith, I. N.: Weakening of the Walker Circulation and apparent dominance of El Niño both reach record levels, but has ENSO really changed?, Geophys. Res. Lett., 34, L18702, https://doi.org/10.1029/2007GL030854, 2007.

Quan, X. W., Hoerling, M. P., Perlwitz, J., Diaz, H. F., and Xu, T. Y.: How Fast Are the Tropics Expanding?, J. Climate, 27, 19992013, 2014

Robock, A.: Volcanic eruptions and climate, Rev. Geophys., 38, 191-219, 2000.

Robock, A.: 20 reasons why geoengineering may be a bad idea, B. Atom. Sci., 64, 14-18, 2008.

Robock, A., Oman, L., and Stenchikov, G. L.: Regional climate responses to geoengineering with tropical and Arctic $\mathrm{SO}_{2}$ injections, J. Geophys. Res.-Atmos., 113, D1610, https://doi.org/10.1029/2008JD010050, 2008.

Russotto, R. D. and Ackerman, T. P.: Changes in clouds and thermodynamics under solar geoengineering and implications for required solar reduction, Atmos. Chem. Phys. Discuss., https://doi.org/10.5194/acp-2018-345, in review, 2018a.

Russotto, R. D. and Ackerman, T. P.: Energy transport, polar amplification, and ITCZ shifts in the GeoMIP G1 ensemble, Atmos. Chem. Phys., 18, 2287-2305, https://doi.org/10.5194/acp18-2287-2018, 2018b.

Sandeep, S., Stordal, F., Sardeshmukh, P. D., and Compo, G. P.: Pacific Walker Circulation variability in coupled and uncoupled climate models, Clim. Dynam., 43, 103-117, 2014.

Schmidt, G. A., Kelley, M., Nazarenko, L., Ruedy, R., Russell, G. L., Aleinov, I., Bauer, M., Bauer, S. E., Bhat, M. K., Bleck, R., Canuto, V., Chen, Y. H., Cheng, Y., Clune, T. L., Del Genio, A., de Fainchtein, R., Faluvegi, G., Hansen, J. E., Healy, R. J., Kiang, N. Y., Koch, D., Lacis, A. A., LeGrande, A. N., Lerner, J., Lo, K. K., Matthews, E. E., Menon, S., Miller, R. L., Oinas, V., Oloso, A. O., Perlwitz, J. P., Puma, M. J., Putman, W. M., Rind, D., Romanou, A., Sato, M., Shindell, D. T., Sun, S., Syed, R. A., Tausnev, N., Tsigaridis, K., Unger, N., Voulgarakis, A., Yao, M. S., and Zhang, J. L.: Configuration and assessment of the GISS ModelE2 contributions to the CMIP5 archive, J. Adv. Model Earth Sy., 6, 141-184, 2014.

Schwendike, J., Govekar, P., Reeder, M. J., Wardle, R., Berry, G. J., and Jakob, C.: Local partitioning of the overturning circulation in the tropics and the connection to the Hadley andWalker circulations, J. Geophys. Res.-Atmos., 119, 1322-1339, 2014.

Seager, R., Naik, N., and Vecchi, G. A.: Thermodynamic and Dynamic Mechanisms for Large-Scale Changes in the Hydrological Cycle in Response to Global Warming, J. Climate, 23, 46514668, 2010.
Seidel, D. J., Fu, Q., Randel, W. J., and Reichler, T. J.: Widening of the tropical belt in a changing climate, Nat. Geosci., 1, 21-24, 2008.

Seo, K. H., Frierson, D. M. W., and Son, J. H.: A mechanism for future changes in Hadley circulation strength in CMIP5 climate change simulations, Geophys. Res. Lett., 41, 5251-5258, 2014.

Shepherd, J. G.: Geoengineering the climate: science, governance and uncertainty, Royal Society, 2009.

Simmons, A., Uppala, S. D., Dee, D. D., and Kobayashi, S.: ERAInterim: new ECMWF reanalysis products from 1989 onwards, ECMWF Newsletter, No. 110, ECMWF, Reading, UK, 25-35, 2007.

Smyth, J. E., Russotto, R. D., and Storelvmo, T.: Thermodynamic and dynamic responses of the hydrological cycle to solar dimming, Atmos. Chem. Phys., 17, 6439-6453, https://doi.org/10.5194/acp-17-6439-2017, 2017.

Solomon, A., Polvani, L. M., Waugh, D. W., and Davis, S. M.: Contrasting upper and lower atmospheric metrics of tropical expansion in the Southern Hemisphere, Geophys. Res. Lett., 43, 10496-10503, 2016.

Song, H. and Zhang, M. H.: Changes of the boreal winter Hadley circulation in the NCEP-NCAR and ECMWF reanalyses: A comparative study, J. Climate, 20, 5191-5200, 2007.

Stachnik, J. P. and Schumacher, C.: A comparison of the Hadley circulation in modern reanalyses, J. Geophys. Res.-Atmos., 116 , D22102, https://doi.org/10.1029/2011jd016677, 2011.

Tandon, N. F., Gerber, E. P., Sobel, A. H., and Polvani, L. M.: Understanding Hadley Cell Expansion versus Contraction: Insights from Simplified Models and Implications for Recent Observations, J. Climate, 26, 4304-4321, 2013.

Taylor, K. E., Stouffer, R. J., and Meehl, G. A.: An Overview of Cmip5 and the Experiment Design, B. Am. Meteorol. Soc., 93, 485-498, 2012.

Tilmes, S., Fasullo, J., Lamarque, J.-F., Marsh, D. R., Mills, M., Alterskjaer, K., Muri, H., Kristjánsson, J. E., Boucher, O., Schulz, M., Cole, J. N. S., Curry, C. L., Jones, A., Haywood, J., Irvine, P. J., Ji, D., Moore, J. C., Karam, D. B., Kravitz, B., Rasch, P. J., Singh, B., Yoon, J.-H., Niemeier, U., Schmidt, H., Robock, A., Yang, S., and Watanabe, S.: The hydrological impact of geoengineering in the Geoengineering Model Intercomparison Project (GeoMIP), J. Geophys. Res.-Atmos., 118, 11036-11058, https://doi.org/10.1002/jgrd.50868, 2013.

Tokinaga, H., Xie, S. P., Deser, C., Kosaka, Y., and Okumura, Y. M.: Slowdown of the Walker circulation driven by tropical IndoPacific warming, Nature, 491, 439-443, 2012.

Vallis, G. K., Zurita-Gotor, P., Cairns, C., and Kidston, J.: Response of the large-scale structure of the atmosphere to global warming, Q. J. Roy. Meteor. Soc., 141, 1479-1501, 2015.

Van der Wiel, K., Matthews, A. J., Joshi, M. M., and Stevens, D. P.: Why the South Pacific Convergence Zone is diagonal, Clim. Dynam., 46, 1683-1698, 2016.

Vecchi, G. A. and Soden, B. J.: Global warming and the weakening of the tropical circulation, J. Climate, 20, 4316-4340, 2007.

Vecchi, G. A., Soden, B. J., Wittenberg, A. T., Held, I. M., Leetmaa, A., and Harrison, M. J.: Weakening of tropical Pacific atmospheric circulation due to anthropogenic forcing, Nature, 441, 73-76, 2006.

Watanabe, S., Hajima, T., Sudo, K., Nagashima, T., Takemura, T., Okajima, H., Nozawa, T., Kawase, H., Abe, M., Yokohata, T., 
Ise, T., Sato, H., Kato, E., Takata, K., Emori, S., and Kawamiya, M.: MIROC-ESM 2010: model description and basic results of CMIP5-20c3m experiments, Geosci. Model Dev., 4, 845-872, https://doi.org/10.5194/gmd-4-845-2011, 2011.

Waugh, D. W., Garfinkel, C. I., and Polvani, L. M.: Drivers of the Recent Tropical Expansion in the Southern hemisphere: Changing SSTs or Ozone Depletion?, J. Climate, 28, 6581-6586, 2015.
Yu, B., Zwiers, F. W., Boer, G. J., and Ting, M. F.: Structure and variances of equatorial zonal circulation in a multimodel ensemble, Clim. Dynam., 39, 2403-2419, 2012. 